\title{
Motivos paganos en mosaicos cristianos y judíos de Oriente: problemática e interpretación (I) ${ }^{1}$
}

\author{
Pau Figueras ${ }^{2}$
}

\begin{abstract}
RESUMEN
ABSTRACT

Muchos de los pavimentos de mosaico

pavimentales descubientos en las antiguas provincias romanas de Oriente

(Siria, Arabia, Palestina) se fechan ya

en el periodo bizantino (siglos $\mathrm{I}$ al VII

(d.C.) y provienen principalmente de las

antiguas iglesias y sinagogas. Sin

embargo, son numerosos los motivos

de tipo mitológico y alegórico pagano

que aparecen en ellos, y no todos los

estudiosos concuerdan en la

interpretación que hay que dar a este

fenómeno.

El fin principal del presente estudio es

un intento de interpretación de tales temas a base de confrontaros en detalle

con judíos, acerca del paganismo en general y de muchos de los motivos en particular. En este primer articulo introductorio se analizan tanto las

Many of the mosaic pavements discovered in the ancient Roman provinces of the East (Syria, Aragia, palestine) are dated to the Byzantine period (fourth to seventh centuries C.E.), mostly recovered from churches and synagogues. Even so, numerous mythological and pagan allegorical motifs appear on them, and not all scholars agree on the interpretation to be given to this phenomenon. The present study aims mainly to interpret these motifs in deetail through their confrontation with the opinons expressed by ancient authors, Christian and Jews alike, abaut paganism in general and some of the motifs in particular. This first anticle is an introduction to the whole subject, analyzing both, the relevant opinions
\end{abstract}

- Este trabajo y el que sigue constituyen parte del estudio realizado con la concesión por la CAICYT de una Estancia de Año Sabático en el Dpto. de Historia Antigua y Arqueologia del CSIC, en el año 1999, dentro del Proyecto de investigación dirigido por la Dra. G. López Monteagudo, "Mosaicos mitológicos hispano-romanos" (PB96-0873).

2 Departamento de Biblia y Próximo Oriente Antiguo de la Universidad Ben-Gurion del Negev (Beer-Sheva, Israel). 
opiniones de los principales autores modernos como la actitud ambivalente de los varios padres de la Iglesia ante la persistencia de la cultura pagana y sus manifestaciones artisticas. expressed by modern researchers as well as the ambivalent approach of the Church Fathers to the persistence of the pagan culture and its manifestations in art.

\section{INTRODUCCIÓN}

La constante labor de excavación de numerosos centros urbanos y rurales en las antiguas provincias romanas de Siria, Fenicia, Arabia y Palestina, ha puesto al descubierto en las últimas décadas un sinnúmero de nuevos mosaicos figurados de gran importancia, tanto por la buena preservación de muchos de ellos como por su riqueza estilística y de contenido temático. Este nuevo repertorio ha venido a juntarse a los ya conocidos y publicados desde principios del siglo veinte, provenientes sobre todo de la antigua Palestina, entonces bajo el dominio turco, luego bajo el mandato británico, y finalmente ya dentro del estado de Israel o del reino hashemita de Jordania. Muchos de estos mosaicos provenían de iglesias, monasterios (Jerusalén, Tabgha, Monte Nebó) y sinagogas (Hammat Tiberias, Bet Alfa), mientras que otros decoraban los pavimentos de villas rurales y mansiones señoriales (Bet Guvrin, Sheikh Zuweid), además del palacio omeya de Jericó (Hirbet elMafjar). Muchos de los nuevos hallazgos en Israel y Jordania son fruto de excavaciones sistemáticas realizadas a gran escala en centros urbanos bien conocidos (Bet-Shean, Cesarea Marítima, Séforis, Mádaba, Petra), pero los hay también totalmente esporádicos, tanto en centros religiosos, judíos (Gaza), cristianos (Um er-Rasas, Birsama) y también samaritanos, como en villas romanas totalmente desconocidas hasta el presente (Lod, 'Ein Ya'el).

A pesar de que prácticamente todos estos descubrimientos, tanto los más antiguos como los más recientes, han sido ya publicados, y en parte sistemáticamente estudiados (Avi-Yonah 1981, Ovadiah 1987, Piccirillo 1993, Talgham 1998), queda todavía por realizar una doble labor de puesta al día: por una parte, un estudio más crítico y más amplio de los detalles estilísticos, las escuelas, las influencias ${ }^{3}$, y por la otra, el estudio más sistemático y profundo de los temas figurativos. En el presente trabajo no nos vamos a ocupar

3 Un buen estudio en esta dirección, aunque muy limitado, y hoy totalmente insuficiente, fue el de E. Kitzinger, 1965, "Stylistic Developments in Pavement Mosaics in the Greek East from the Age of Constantine to the Age of Justinian", en La Mosaïque Gréco-Romaine, Paris 29 Août 3 Septembre 1963. Paris, págs. 341-352. El primero en sistematizar el estudio de los mosaicos de Palestina habia sido Michael Avi-Yonah, quien ya entre los años 1932 a 1935 había publicado su fundamental trabajo: "Mosaic Pavements in Palestine" (Quarterly of the Department of Antiquities of Palestine, II, III, IV), trabajo que fue mucho más tarde, ya después de su muerte, acertadamente reeditado (AVi-YONAH 1981). 
más que de un aspecto que se refiere directamente al contenido temático de los mosaicos figurados. Es el tema ya apuntado en el título, de la persistencia de los motivos mitológicos o simplemente paganos en su origen, que continuaban apareciendo en una época y un contexto religioso que ya nada tenian que ver con el panteismo y la mitologia de griegos y romanos ${ }^{4}$. En efecto, existe una problemática en el estudio de estos mosaicos del periodo que acostumbramos a llamar «bizantino», esto es, datado en los siglos IV al VII, cuando el imperio romano de Oriente tenía su capital en Bizancio o Constantinopla. El cristianismo había penetrado rápidamente en todas las antiguas provincias, aunque no con tanta rapidez y profundidad como pudiéramos pensar. Había penetrado por canales muy distintos en todas las capas de la sociedad, y se intentaba cristianizar tanto las ideas como las costumbres, después de que la población rural aceptara el bautismo y se fundaran iglesias y monasterios por doquier. La introducción del cristianismo no siempre fue fácil ni incluso promovida o favorecida por las autoridades locales. De ello tenemos documentos históricos de primera mano, como la vida de Portirio de Gaza por su diácono Marco de principios del siglo v, y el testimonio de fidedignos historiadores locales, como Sozomeno, de la misma época, que por lo general no demuestran interés alguno en tergiversarnos la verdad de los hechos que narran. Lo cierto es que el trasfondo mitológico de la cultura clásica griega, que era sin duda la de los grandes escritores cristianos de la época, continuaba flotando en la superficie de toda expresión artística, tanto literaria como visual. Lo mismo debemos decir de los más intelectuales entre los maestros religiosos judíos de la época, no sólo en la lejana diáspora de Roma y las provincias del Norte de Africa, sino en la propia tierra de Israel, en las provincias de Palaestina Prima y Secunda, o sea en Judea y Galilea, así como en la provincias de Arabia, que comprendian principalmente el antiguo territorio nabateo, y en las de la gran Siria, que se extendían desde los altos del Golán junto al lago de Tiberiades hasta los confines del imperio, en Dura Europos, a las orillas del Eufrates. La cultura griega era no sólo conocida entre los judíos de la Diáspora, que habían dado al mundo un exégeta tan helenizado como Filón de Alejandría, sino que en la propia tierra de Israel formaba parte del curriculum de estudios de los jóvenes que iban a ser promovidos a rabinos. No es casualidad que encontremos en un lugar tan sagrado para los judios del siglo III como la necrópolis de Bet Shearim, donde estaba enterrado nada menos que el Patriarca Judá, promotor de la redacción de la Mishná, sarcófagos decorados con relieves de máscaras, leones, cabezas taurinas e incluso la escena de Leda y el Cisne (Avi-Yonah 1981: Pls. 26 y 38, 1).

\footnotetext{
4 El tema fue abordado hace poco por J.M. BLAZOUEZ (1990), pero su trabajo trata casi exclusivamente del tema dionísiaco. Por otra parte, los motivos de los Trabajos de Hércules y de la leyenda de Hipólito, que también menciona, no fueron jamás usados en la decoración de las iglesias.
} 


\section{La problemática}

No hay duda pues que existe una problemática de interpretación, que nos plantean hoy los motivos mitológicos y las representaciones alegóricas que afloran en las escenas figuradas en los mosaicos pavimentales de iglesias y sinagogas. Y si quisiera reducirse la magnitud del problema, deberíamos por lo menos discutir la profundidad y la extensión del uso de tales motivos en una época y unos ambientes que no corresponden, en nuestra perspectiva histórica algo borrosa, a lo que nos imaginaríamos hoy. Claro está que el problema de interpretación y apreciación no deberian tampoco reducirse a los mosaicos, puesto que poseemos igualmente relieves judios de fachadas y entradas monumentales de sinagogas en los que aparecen victorias ${ }^{5}$ y tritones ${ }^{6}$, por ejemplo, y objetos en marfil de uso personal o tal vez litúrgico decorados con imágenes desnudas de Afrodita ${ }^{7}$ o de Eros ${ }^{8}$. Sarcófagos cristianos de plomo podian estar decorados con varias cruces a la par que con relieves estampados de figuritas aladas representando las estaciones del año ${ }^{9}$. Nos cuesta admitir que nadie se diese cuenta de lo contradictorio de tales imágenes con la doctrina judía y cristiana estrictamente monoteista, y en teoría totalmente anicónica, que con los textos más conocidos del Antiguo Testamento hasta el último de los escritos del Nuevo se proclamaba en cualquier acto religioso. Uno puede admitir que, cuando se trata de una imagen esporádica de uso personal, no se le diera importancia alguna. Pero la cosa no puede ser ya tan "inocente" cuando mosaicos con los signos del Zodíaco dispuestos alrededor del dios Helios eran el motivo decorativo más normal en las sinagogas de Palestina (Fig. 1), y las figuras de Helios y Selene aparecian igualmente en el centro de lo que sería un patio interior en el monasterio cristiano de Bet-Sheán o Scitópolis. No nos extraña demasiado ver que en casas señoriales de Antioquía se continuase decorando los suelos de triclinios y otras salas con figuras alegóricas de las virtudes humanas, que

5 Así por ejemplo sobre el dintel del portal de la sinagoga de Ed-Dikke (GOODENOUGH, vol. 3, fig. 524, vol.1, pág. 206).

- Pueden verse todavia en los fragmentos del friso de la sinagoga de Cafarnaúm, expuestos hoy en el patio del recinto.

Asi en un marfil decorado con la figura de Afrodita Anadyomene, descubierto en la excavación de la iglesia bizantina de Ostrakine, en el Norte del Sinaí (OREN, 1982: Fig. 25), o una estatuilla de otra mujer desnuda encontrada dentro de una tumba cristiana en Beersheva (FIGUERAS, 1980:160)

8 Fueron encontrados en varios contextos bizantinos y sobre todo en Mampsis, antigua ciudad nabatea del Néguev (RosentHal, 1976).

9 Aparecen en los grandes fragmentos hallados hace pocos años en los campos del kibuts Nirim, la antigua ciudad de Menois, en el sur de Israel (RaHMani, 1996). 

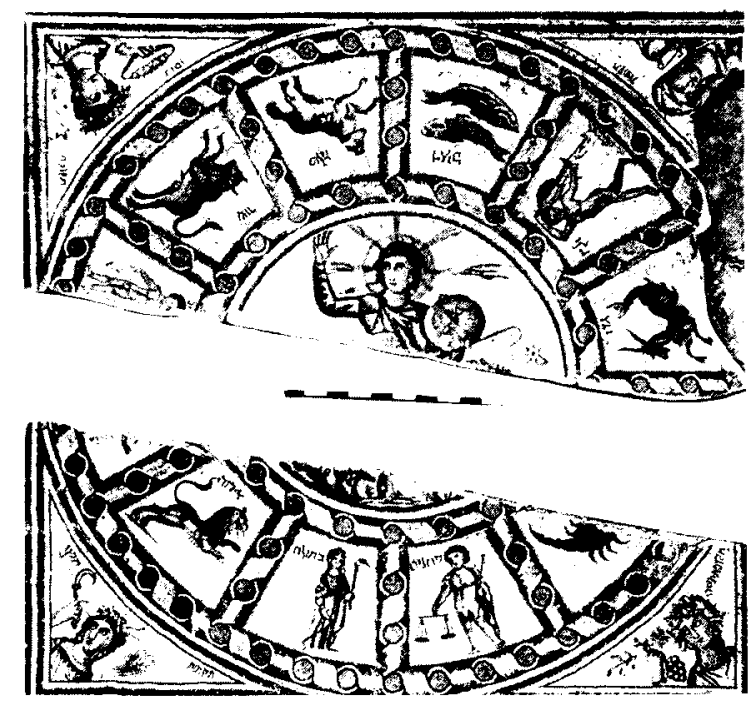

Fig. 1. Rueda del Zodiaco, Sinagoga de Hammat Tiberia (Avi-Yonah 1981, pl. 61).

eran apreciadas tanto por los filósofos neoplatónicos como por los maestros cristianos. Pues ciertamente se daba un significado simbólico a los viejos mitos en los mosaicos tardorromanos de Antioquía y Apamea. Y si no somos capaces de interpretar su simbolismo moralizante, nos perdemos justamente aquello que había sido la intención de quienes los habian ejecutado o los habian encargado (Balty 1988; López Monteagudo 1997). Pero sí que algo nos sorprende que la figura central del mosaico pavimental de la iglesia de los Apóstoles de Mádaba sea la de un busto semidesnudo de mujer representando el mar, con su inscripción Thalassa, bajo los atributos de la diosa Tetis. O que el dios Océano aparezca reproducido de cuerpo entero en el suelo de la iglesia recientemente descubierta en Petra. $Y$ ¿por qué tiene que ser un joven centauro el que sostiene el cartel conteniendo la inscripción "Dios ayuda», en el corredor de una casa noble del siglo VI en la ciudad de Séforis? (Fig. 2). Los casos se multiplican, y uno siente la necesidad de explicarse con la máxima claridad posible este interesante fenómeno del uso de mitos, alegorías y símbolos de origen pagano por parte de judios y cristianos.

No estamos ya en los albores del cristianismo, cuando les era todavia muy difícil a los artistas decorar unos cubículos de catacumba o un sarcófago con temas alegóricos o históricos que expresaran la fe en una salvación eterna de los difuntos por parte de un Dios salvador. El mensaje, la buena nueva de la posibilidad de salvación individual, había conquistado el mundo pagano. El repertorio iconográfico había sido ya prácticamente fi- 


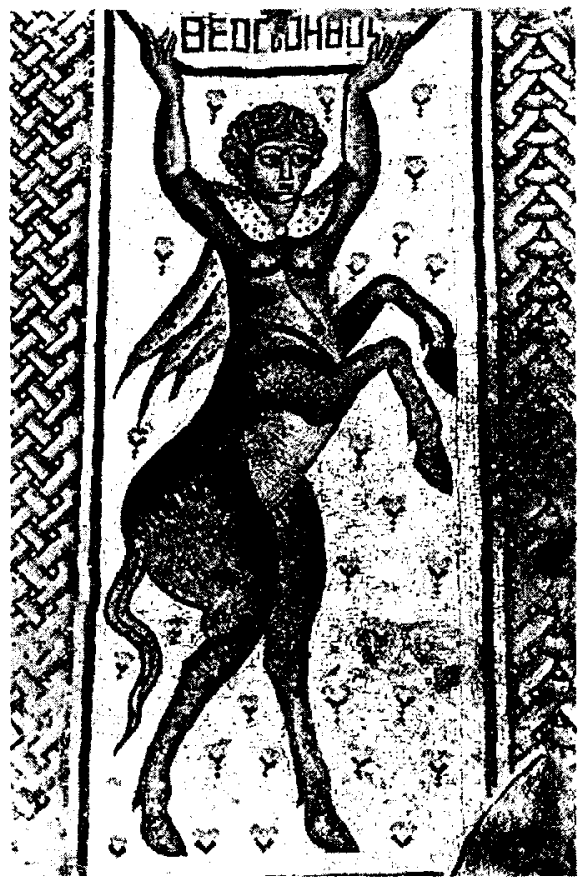

Fig. 2. Centauro, Casa del Festival del Nilo, Séforis (Weiss-Netzer 1994, pág. 50).

jado desde hacía ya varias generaciones, cuando en los siglos $\mathrm{V}$ y VI, los de más esplendor en la decoración musiva de las iglesias, los temas paganos eran empleados todavía con profusión. Uno se pregunta si no fue justamente la disposición teodosiana que prohibía la decoración de los pavimentos con figuras cristianas y con cruces la que indujo a ciertos artistas o a ciertos obispos a dirigirse de nuevo al repertorio iconográfico más antiguo, tanto al directamente pagano como al que podríamos llamar más "neutro", el mundo de la naturaleza, fauna y flora, estaciones del año, trabajos agrícolas, la tierra, el mar, el Nilo, la pesca y la caza, y todo ello con una intención, directa o no, de expresar lo que les estaba prohibido hacer directamente con imágenes sagradas del repertorio bíblico o tradicional cristiano, que siempre habrian sido más fácilmente entendidas. En todo caso, el hecho de que en casas judias y sinagogas se hacia igualmente uso de temas paganos, que no pueden ser casuales sino muy intencionados, como veremos, pone en evidencia que aquellos temas no sólo continuaban muy vivos en el recuerdo de las familias de tradición pagana sino que habían pasado a ser patrimonio cultural de todos, y eran usados como cantera de materiales pedagógicos muy eficaces, tanto para cristianos como para judíos. 
Pues es evidente que si, por una parte, muchos de los motivos escogidos para la ornamentación del interior de casas y edificios públicos podian ser puramente decorativos, sin intención pedagógica, religiosa o no, por la otra no, puesto que tenemos pruebas evidentes de que los autores de los mosaicos habian escogido sus temas deliberadamente. Los habian concebido con una intención simbólica o alegórica. Asi lo dejan entender algunas de las inscripciones acompañantes ${ }^{10}$. Las escenas o motivos paganos eran portadoras de un mensaje bien preciso, comprensible por parte de aquellos a quien iba dirigido, que eran tanto los clérigos como los simples fieles que asistían a la liturgia en caso de las iglesias cristianas, los habitantes y visitantes de las casas particulares, o los fieles judíos que asistían a los oficios sinagogales. Las figuras llevaban, o por lo menos podían llevar, un mensaje. Y es del interés de todos tratar de poner en claro cuál pudiera ser aquél.

Hay dos términos específicos que fueron empleados con profusión en las inscripciones dedicatorias que acompañan con frecuencia los mosaicos, y que podríamos tomar como punto de partida para la comprensión del tema que nos ocupa. Por cierto que los dos mismos términos se encuentran igualmente en otros contextos, tanto en dedicatorias como especialmente en epitafios. Esos términos son, con sus derivados y sus sinónimos, los de boethia y sotería. Ambos habian sido heredados del mundo pagano, y fueron empleados con la misma profusión y con semejanza de significado tanto por judíos como por cristianos para expresar los grandes intereses del hombre delante de Dios: la esperanza de ser "ayudados", asistidos en el camino hacia la eternidad, y finalmente "salvados", esto es, admitidos a una vida de eterna felicidad en Dios.

Es interesante constatar que la palabra clave que acompaña el tema decorativo de tipo mitológico en el mosaico pavimental de una casa, judía, al parecer, que ha venido llamándose Bet Leontis (casa de Leontis) en Scitópolis, la antigua y actual ciudad de Bet Sheán, sea el de boethía. Y no es pura casualidad. Aquel mosaico nos muestra a Ulises atado al mástil de su barco mientras pasa navegando por delante de una mujer desnuda cavalgando sobre una sirena, a la par que otra barca con su tripulante navega delante de otra sirena, probablemente la monstruosa Scyla, que aparece tocando su mágica flauta (Fig. 3). Una inscripción que acompaña

No siempre resulta fácil encontrar la relación que pueda existir entre el texto de una inscripción y el mosaico que la acompaña. Un caso a propósito es la de Pablo, obispo de la ciudad de Apamea en el s. VI, que ilustra con figuras de animales las referencias a su propia ortodoxia. Janine Balty ha sabido interpretar magistralmente el conjunto (BALTY, 1977: 140-143), aunque no todo el mundo estará de acuerdo con ella. 


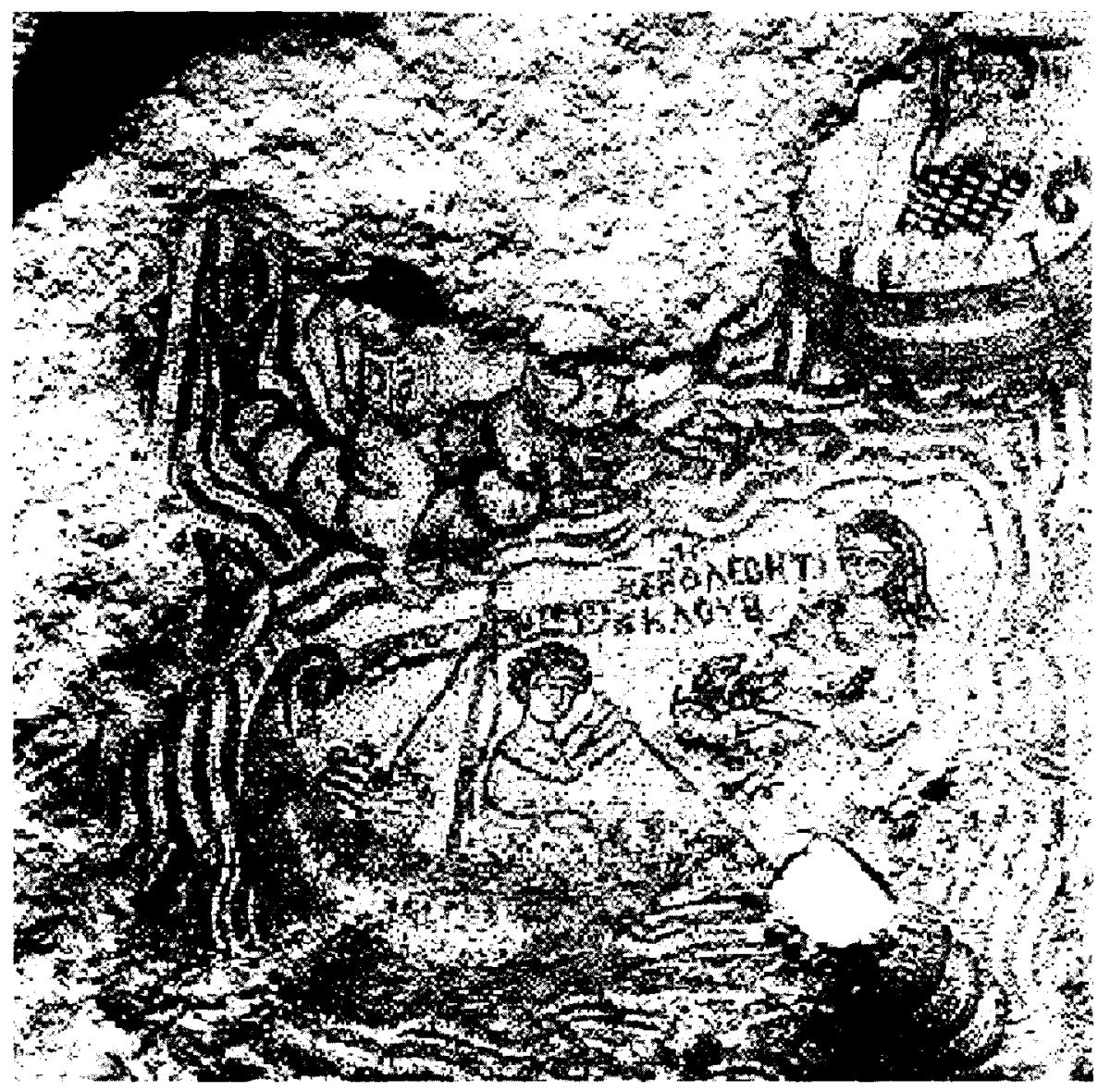

Fig. 3. El monstruo Scyla y Ulises atado al mástil. Bet Leontis, Bet Sheán (Hachlili 1988, pl. 68).

la escena dice textualmente: "Señor, ¡ayuda a Leontis Klubas!" (Roussin 1981: 14, Fig. 7). Es evidente que la escene expresa la necesidad sentida por Leontis de implorar la ayuda divina en esta vida, ante las asechanzas del enemigo que podría impedir la salvación eterna deseada para sí y para los suyos. El mosaico no es pagano. Podría ser en todo caso cristiano, si no fuera por el hecho de que la casa en que se encuentra esté en el mismo complejo arquitectónico que una pequeña sala sinagogal, marcada por una menorá central (Levine 1981:84).

Los dos términos aducidos, por otra parte, son lo suficientemente abstractos y generales para poder aplicarlos sin ningún reparo al esclarecimiento de la mayoría de mosaicos de pavimentos en las iglesias cristia- 
nas. Puesto que, cualquiera que sea el grado de simbolismo que se quiera dar a los pavimentos figurativos en edificios eclesiásticos, el principal mensaje que podemos suponer que contienen para el gran público que los contempla, el mensaje más auténticamente cristiano, siempre terminará en la idea de un final feliz para la presente vida en este mundo terreno y la esperanza de una vida renovada en el mundo venidero, transcendente. Se trata no ya de reducir el mensaje a la felicidad individual sino de ensancharlo a la colectiva, en un mundo renovado en el que las creaturas, es decir, los hombres salvados, vivirán en una paz eterna. Renovación de vida en un Paraíso celestial ${ }^{11}$, cuyos cuatro abundantes rios, simbolo de la plenitud de vida, pueden todavía llevar nombres bíblicos, pero que en varios casos se reducen a la sola imagen del gran Nilo, el rio de la abundancia por excelencia en la tradición helenística, representado por la figura de un hombre de mediana edad. Es el caso de la casa de Leontis, que no es pues el único, pero nos proporciona una clave muy segura para la correcta interpretación de la mayoría de los motivos mitológicos o simplemente alegóricos tradicionales ${ }^{12}$ en mosaicos judios y cristianos que, dado su contexto arqueológico o su cronología, deben de tener un significado o incluso llevar un mensaje religioso o transcendente, ya sea judío o cristiano.

Lejos de nuestra postura considerar que cualquier figura capaz de llevar un potencial simbólico estuviera representada realmente con esta intención en todos los casos, como si no pudiera ser que el uso de tales motivos fuese sencillamente decorativa. Cada caso tiene que ser examinado en sus circunstancias y su contexto arqueológico. Nosotros vamos a intentar ir por la vía crítica, buscando el soporte en la literatura contemporánea para justificar nuestra interpretación. Donde aquélla no existe, es difícil pronunciarse. Lo cierto es que tenemos abundante material literario, no sólo de la escuela neoplatónica, sino también de lo producido por numerosos autores cristianos, ya a partir del siglo II. Nada mejor que el repaso de la literatura patrística oriental para darnos cuenta de la importancia que adquirieron los antiguos mitos clásicos como ejemplos de virtud o de esperanza de realidades transcendentales. $Y$ esto hasta el punto de que, en cierto momento, no sólo judíos y cristianos aceptan sin oposición el uso de imágenes paganas y de antiquos mitos para expresar sus pro-

\footnotetext{
$"$ Representado en innumerables pavimentos musivos de iglesia por figuras de animales salvajes y domésticos, generalmente alrededor de un sujeto divino.

12 En un mosaico de casa señorial en Séforis, la llamada casa de la fiesta del Nilo, el propio país de Egipto, identificado por una inscripción, está representado por una figura femenina también recostada y sosteniendo el cuerno de la abundancia, junto a las murallas de la misma ciudad de Alenjadría.
} 
pios conceptos religiosos, sino que parece haber habido una reacción pagana dirigida a traer de vuelta a sus dominios los valores tradicionales paganos de ciertos temas que estaban siendo empleados por sus oponentes en el plano de la religión (Balty 1988) ${ }^{13}$. Por otra parte es difícil, en numerosos casos, decidirse por la interpretación auténtica que debe ser dada a tal o cual figura o escena mitológica, particularmente cuando inscripciones paganas y cristianas aparecen en un mismo contexto arqueológico. Pero este último caso no se se da, por lo menos en Oriente, tratándose de mosaicos.

\section{Principales conceptos expresados bajo ropaje mitológico}

Con el fin de hacer más comprensibles la extensión y la importancia del problema, adelantamos aquí una lista de todos aquellos temas que se representan en mosaicos bajo apariencias de mitología o de figuras alegóricas clásicas, conceptos obviamente cristianos o judíos:

1. Victoria sobre los males que acompañan al hombre en su camino hacia la eternidad: Ulises atado al mástil a fin de escapar a las tentaciones de Scylla (Beit Leontis). Paisaje paradisiaco: Animales en paz (muy frecuente), ríos y escenas nilóticas (Beit Leontis, Tabga, Haditha, El Mukhayyat).

3. El hombre divinizado (David, Jesucristo, Adán) sentado en su trono, rodeado por animales en paz (como Orfeo) y por las fuerzas del mal subyugadas (Jerusalén, Gaza, Huarte) (Fig. 4).

4. Victoria y alegría de las almas en libertad: escenas de danza y procesiones dionisiacas (Scitópolis, Séforis, Gerasa, Erez, Sheikh Zuweid) (Fig. 5).

5. Esperanza de la victoria escatológica: Centauro (Séforis, Sheikh Zuweid) (Fig. 2).

6. El poder creador de Dios, manifestado en su creación: Ge (Hanita y Tel Malhata (?), iglesias de Mádaba, Monte Nebó y de Petra) (Fig. 6),

Es importante la aportación de Janine Balty en su interpretación de ciertos mosaicos de tema mitológico descubiertos en las casas señoriales de la región de Antioquia y de Apamea (BALTY 1988; 1995:34-48), aunque uno no puede dejar de preguntarse hasta qué punto tal interpretación es totalmente justificada cuando no existe un soporte literario directo. Nosotros hemos recurrido a una explicación semejante, mutatis mutandis, para interpretarnos el fenómeno de las pinturas judías de la sinagoga de Dura Europos. En este caso, la reacción se daba por parte de los judios, que habrian querido retraer a su propio dominio los temas de la historia de salvación del pueblo de Israel, de los que parecian haberse adueñado los cristianos (FIGUERAS, 1996). 


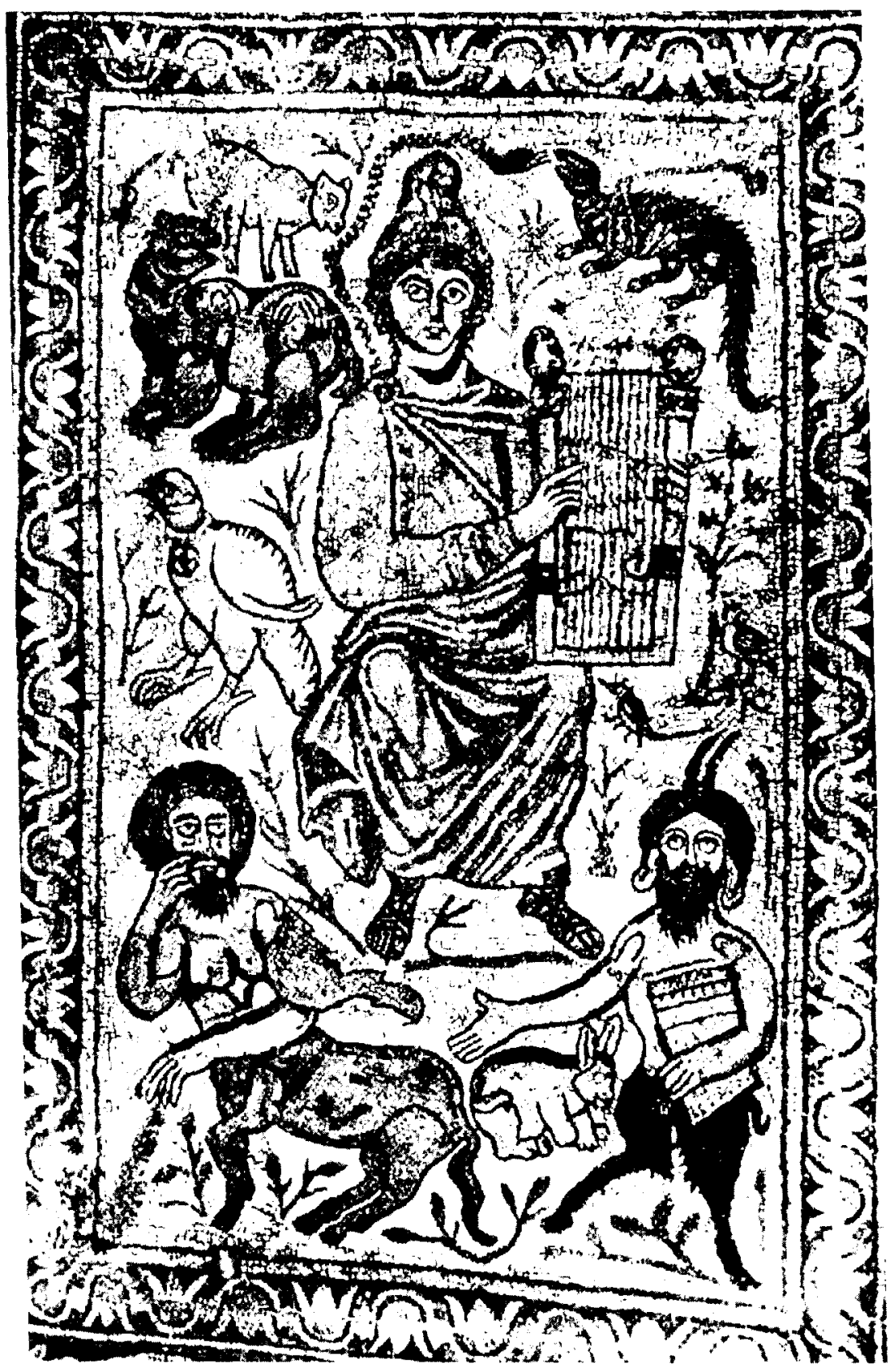

Fig. 4. Orfeo, en sala transformada en capilla, Jerusalén (Avi-Yonah 1981, pl. 51). 


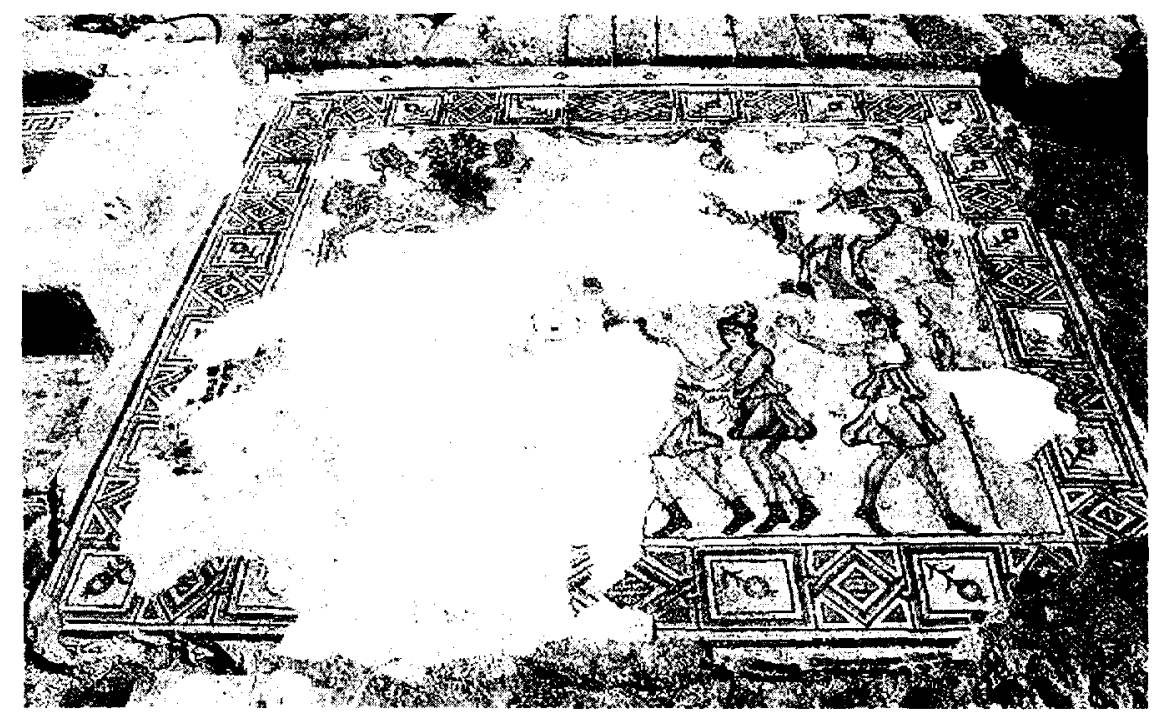

Fig. 5. Procesión de Amazonas, casa del Festival del Nilo, Séforis (Weiss-Netzer 1997, pl. 3).

Thalassa (Mádaba) y Océano (Petra) rodeadas de hombres, animales, plantas y frutos.

7. Dios, dador de la vida y poder central sobre el tiempo y el mundo: el dios Helios (y la diosa Selene) rodeados por la rueda del tiempo y el espacio: signos del Zodíaco, meses, y estaciones del año (sinagogas de Israel, monasterio de Bet Shean, iglesias de Qabr Hiram, Petra) (Fig. 1).

8. Dos leones, símbolos paganos de fuerza, flanqueando el armario santo de la Torá (Bet Alfa), la menorá (Nirim) (Fig. 7) o las inscripciones en la entrada de la sinagoga (Hammat Gader, Hammat Tveria).

Otros muchos temas iconográficos de los mosaicos, particularmente de los cristianos, podrían asimismo relacionarse fácilmente con antecedentes paganos, y de entre ellos destacaremos el de las escenas de vendimia ${ }^{14}$ (Bet Sheán, El Mekhayyet) (Fig. 8), el del pastor ${ }^{15}$ (ShueifatChalde, Birsama), el de la mujer amamantando a su bebé ${ }^{16}$ (Birsama)

14 Son escenas dionisiacas, generalmente usadas para expresar ideas escatológicas en contextos funerarios, como los sarcófagos. Ya en el sarcófago de Costanza, en Roma, tenemos una adopción cristiana del tema (BLȦQUEZ, 1990: 378, Fig. 18).

15 También usado en conexión con el tema escatológico del Paraíso.

16 Su posible conexión con la iconografía de Isis-Horus la expusimos ya en la nota que publicamos con ocasión del descubrimiento del mosaico (FIGUERAS, 1992), aunque nadie 


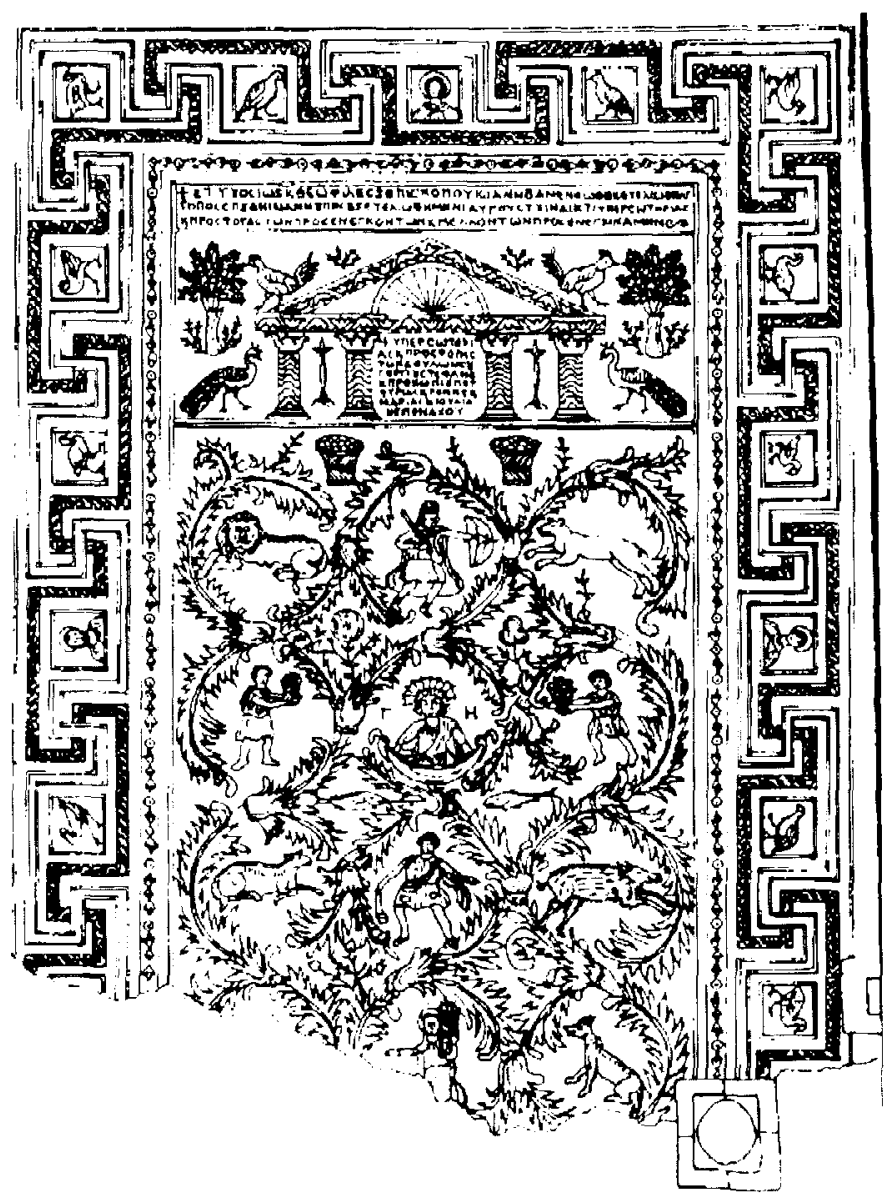

Fig. 6. Mosaico con la figura de Ge y los Karpoi, El Mekhayyet, Monte Nebó (Piccirillo 1986b, pág. 38, fig. 51).

(Fig. 9), así como a la presentación de ciertas figuras que podrían haberse inspirado en antecedentes profanos, como las de Moisés y del propio Jesús tal como aparecen en el mosaico absidal de la iglesia justiniana del Sinaí (Fig. 10).

parece haberla aceptado hasta el presente. Hoy añadiriamos la posible relación con los grupos de Afrodita-Eros y Nysa-Dionysos (véase LIMC, "Nymphai" nn. 84, 86a, 86b, "Aphrodite", etc.). 


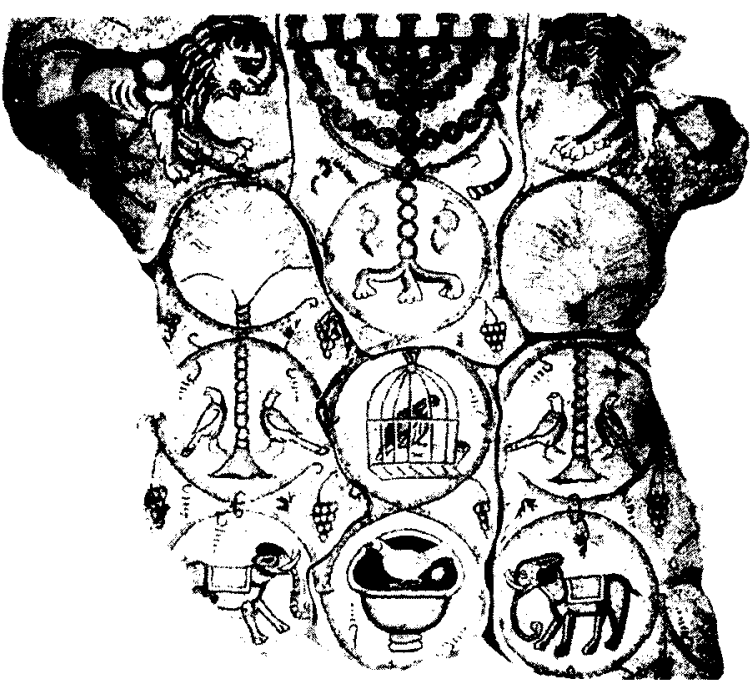

Fig. 7. Leones custodiando la Menorá. Sinagoga de Nirim (Hachlili 1988, pl. 87).

El debate sobre el sentido que debe darse en cada caso a la antigua iconografía cristiana y judía no se ha terminado, al igual que no hemos llegado al final de los descubrimientos de nuevos mosaicos. Hay que tratar pues, por todos los medios, de resolver el problema de la interpretación, ya que las opiniones están divididas en campos antagónicos. Tomar una postura sin más criterio que el propio gusto, de tendencia más realista o más simbolista, es sencillamente injusto y contrario a lo más elemental del método científico. Negar que exista un simbolismo detrás de un motivo pagano porque éste no corresponde a la religión del grupo cuyo lugar de culto decoraba, puede ser tan falso como querer encontrar un sentido simbólico a cualquier motivo decorativo que había tenido sentido en otro contexto. Por lo general, parece bastante obvio que las opiniones se dividen justamente entre los que, además de los mosaicos, son conocedores de la literatura patrística (o judia) de la época en cuestión, y los que no lo la conocen. A los primeros, familiarizados como están con las numerosas referencias a la mitología que se encuentran en los Padres, no les es difícil aceptar que exista una conexión buscada entre el motivo pagano, la moraleja filosófica, y un punto de la doctrina cristiana que aquel motivo pagano puede sencillamente ilustrar o evocar. A los que conocen el uso que los Padres de la Iglesia hacían de temas paganos con intención educativa e ilustrativa, les resulta fácil comprender el empleo de escenas mitológicas directas que se hacia en el arte de los primeros siglos bizantinos, y que se extendió tanto por Oriente como por Occidente hasta bien entrada la E.dad 


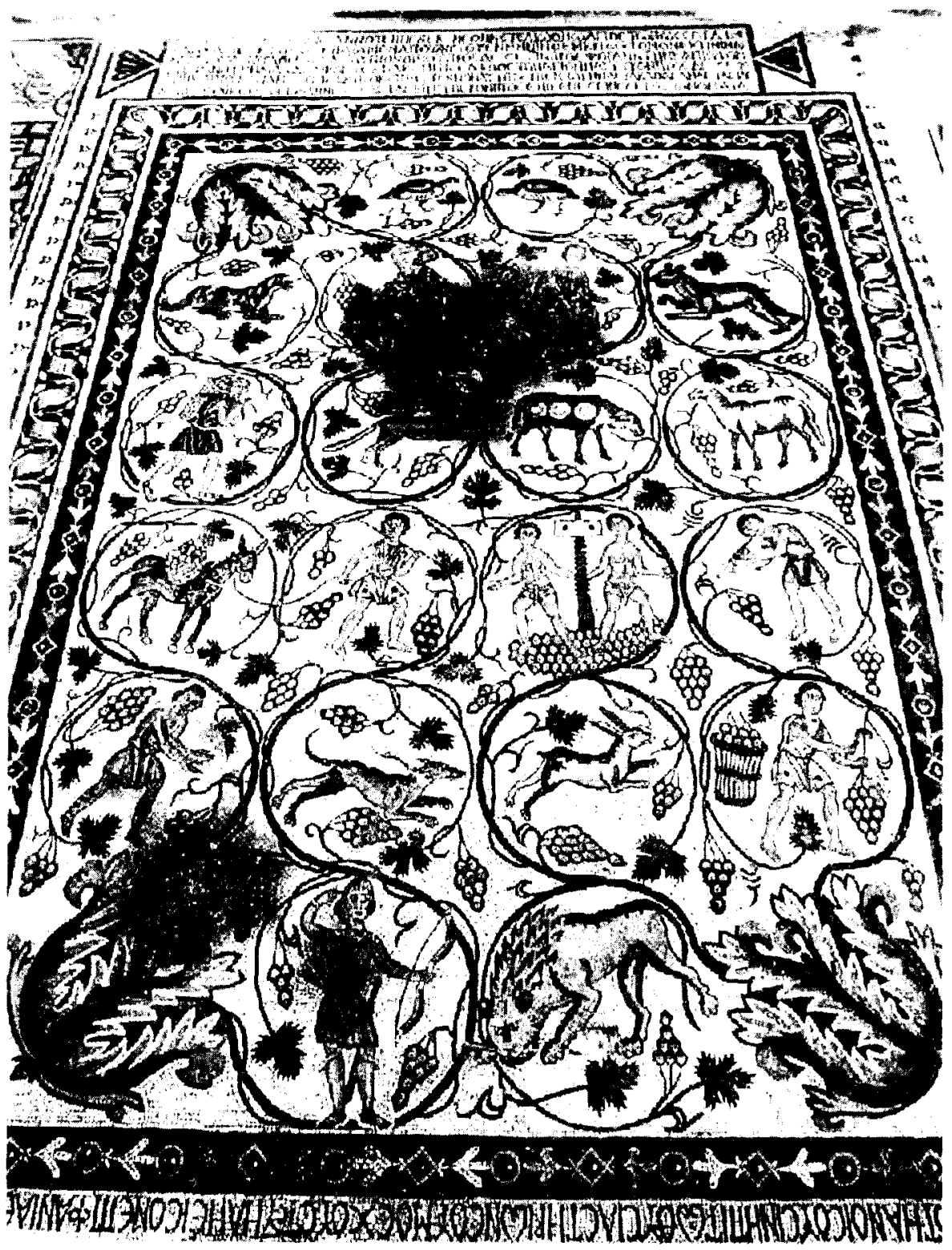

Fig. 8. Trabajos agrícolas. Iglesia de El Mukhayyet, Monte Nebó (Piccirillo 1986b, pág. 16, fig. 27). 


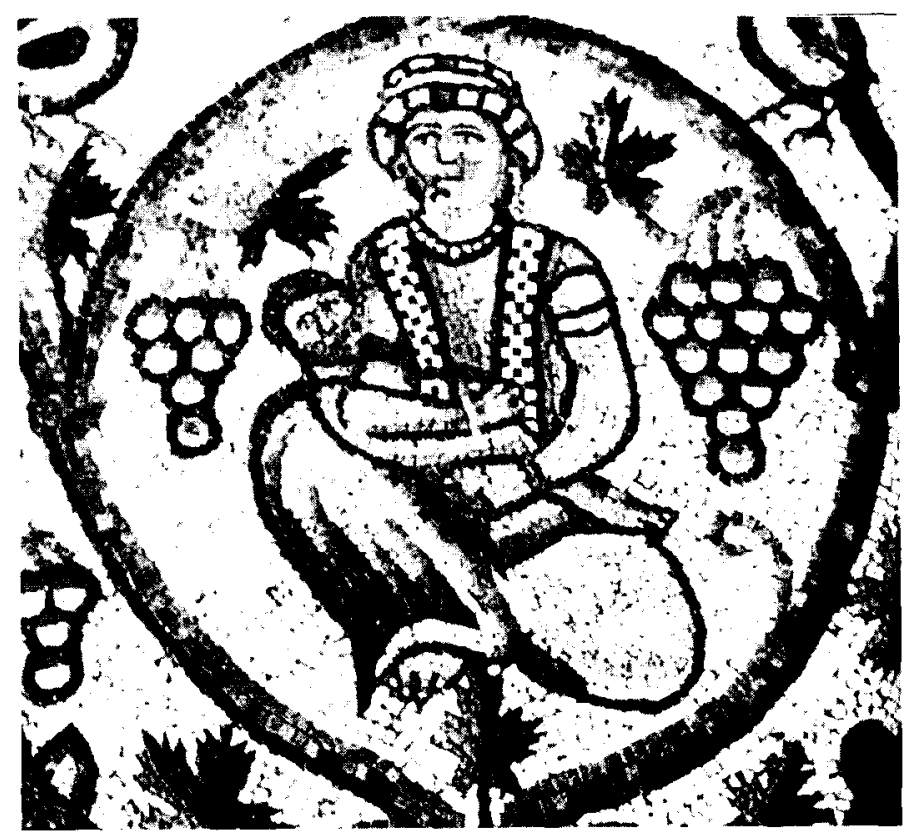

Fig. 9. Madre amamantando a su bebé. Iglesia de Birsama (Gazit-Lender 1992, pág. 39)

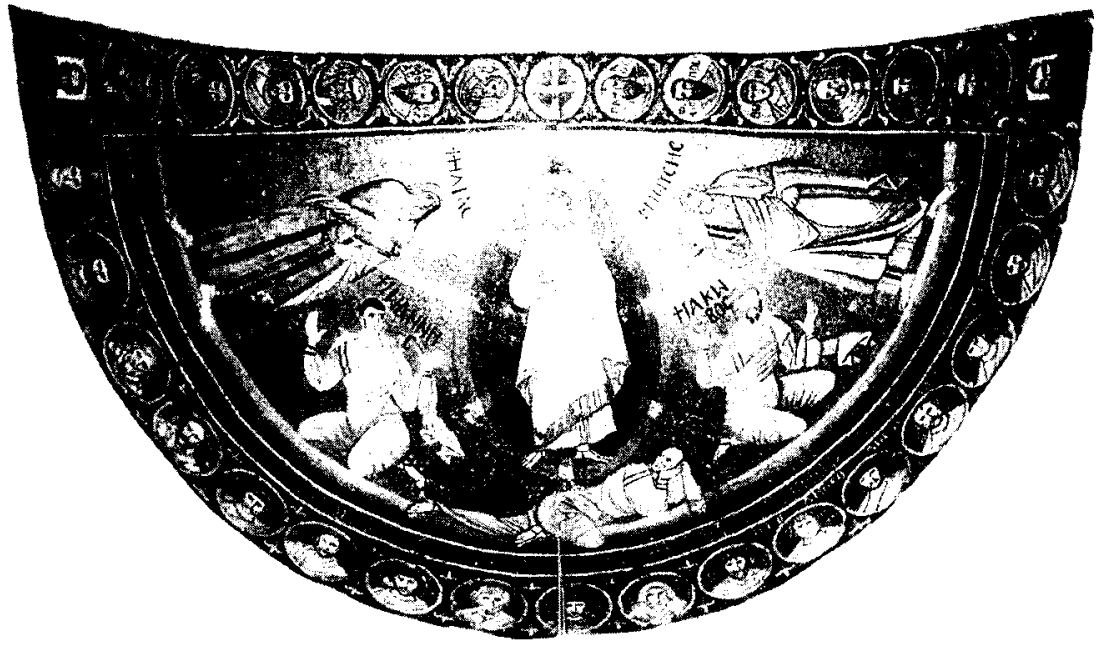

Fig. 10. Mosaico de la Transfiguración. Sinaí (Potin 1993, pág. 40, fig. 39). 
Media. Otros, menos familiarizados con dicha literatura, vieron, por ejemplo, los mosaicos de la llamada Sala de Hipólito (Fig. 11) y otros de cercano contexto como una reacción anticristiana en plena época cristiana, lo que es muy improbable ${ }^{17}$.

Recientemente se ha hecho un esfuerzo para resumir los principales argumentos aducidos por los dos grupos antagónicos de estudios que están en favor o en contra de una interpretación simbólica de las escenas y temas que aparecen en los mosaicos, que o bien son directamente mitológicos en sus figuras, como Dionisos, Ulises, Océano, Ge, Tyche (Fig. 12), etc, o bien tienen su origen en la mitología griega o en contextos paganos tradicionales

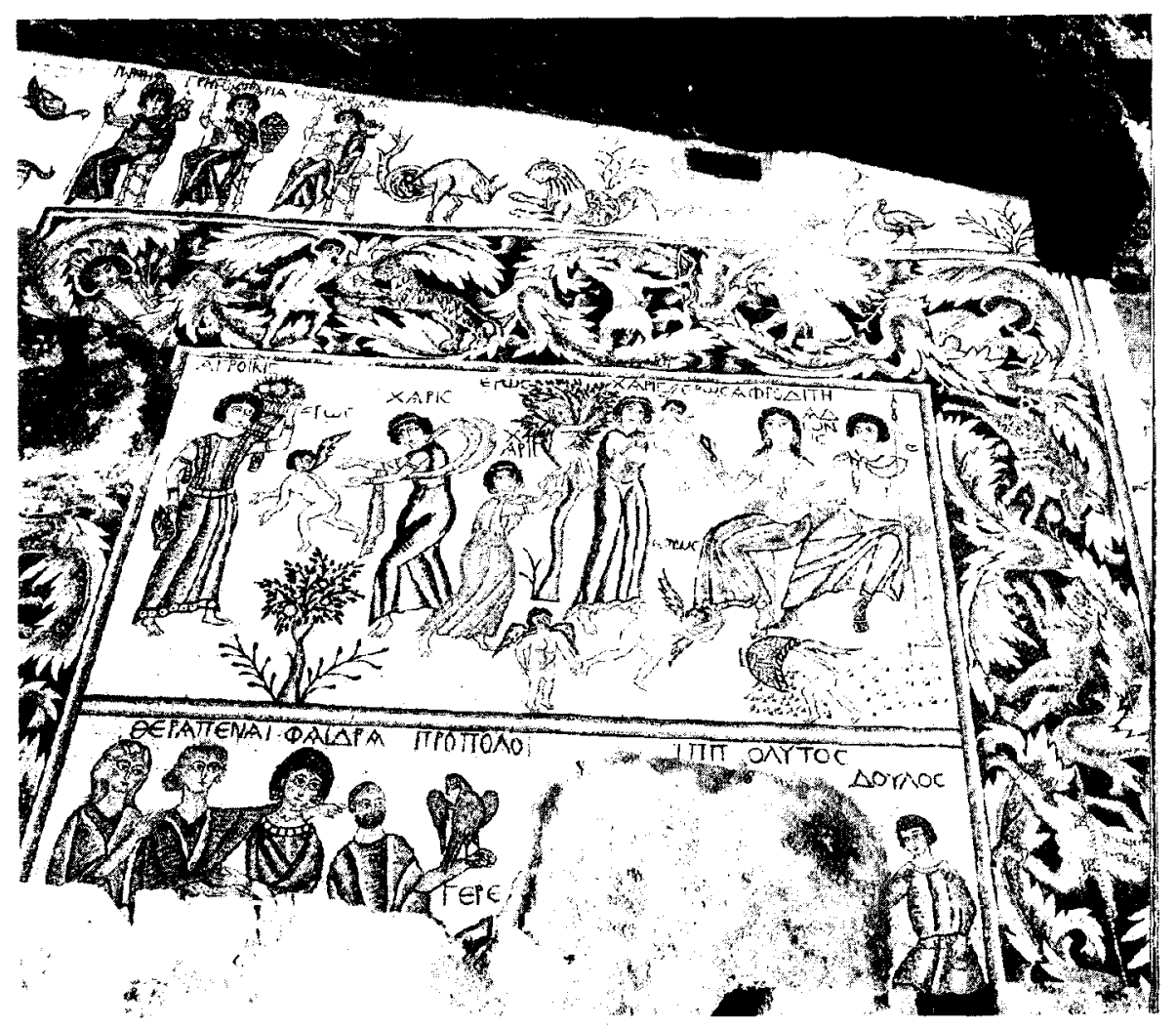

Fig. 11. Sala de Hipólito. Mádaba (Buschhausen 1986b, pl. IX).

${ }_{17}$ Comentario de Condurachi a la presentación hecha por Zayadine de los mosaicos de Jordania (ZAYADINE, 1986:429-430). 
pero que son «neutros" en sí mismos, tales como escenas de caza, flora y fauna, trabajos del hombre, recipientes con agua, etc. En cuanto a la división de opiniones en la interpretación, tanto de temas judios como cristianos, descubiertos en Israel y Jordania, los principales argumentos han sido resumidos por Talgam (1998:84ss) en los tres grupos siguientes:

1. Existe una fuente no particularmente religiosa para tal iconografía, y especialmente en el Norte de Africa y en Sicilia.

2. Los mismos temas que fueron representados en muchas sinagogas existían también en edificios de carácter secular, y fueron usados incluso más tarde por artistas omeyas.

3. Existen muy pocos textos del periodo romano-bizantino que se refieran a la decoración de los edificios no religiosos y religiosos.

Entre los estudiosos que han negado un significado simbólico a los mosaicos destacan Biebel (1938) y Crowfoot (1941).

Muy pocos autores cristianos o judíos de la época se refirieron a la decoración musiva de los pavimentos. Entre ellos, los más importantes fueron:

1. Nilo Sinaíta (AD 430), sobre escenas de caza, que él preferiría fueran cambiadas por escenas del Antiguo y del Nuevo Testamento.

2. Juan de Gaza (siglo vi) sobre las pinturas de las termas de Gaza: alegoría del cosmos, a la que da sentido cristiano la cruz que lo preside todo en el punto más alto.

3. Un himno siríaco sobre la catedral de Edesa, que sugiere una interpretación bíblica y cósmica a todo el programa decorativo.

4. La referencia de Coricio de Gaza (siglo vi) a la pintura de animales y escenas nilóticas en la iglesia de San Sergio de Gaza.

A falta de textos explicativos, uno busca instintivamente la luz en las inscripciones que frecuentemente acompañan a los mosaicos. La verdad es que son pocas las que se refieren a los temas musivos. Por otra parte, el decreto imperial del AD 427 contra la representación de cruces en el suelo de las iglesias indica la sensibildad que existia por no pisar los motivos sagrados. Los judios no tuvieron en cuenta tal cosa, y representaron objetos y temas bíblicos en los suelos de las sinagogas. Los mosaicistas de pavimentos de iglesia prefirieron permanecer en el dominio de lo secular, teniendo así un campo más reducido de donde poder escoger los temas que aquellos que trabajaban en la decoración mural. 
Entre los estudiosos convencidos del valor alegórico de los temas representados en los mosaicos de pavimento tenemos a S. Saller, B. Bagatti y A. Grabar. Para ellos, los animales representan la obra creadora de Dios. Las escenas de la vida cotidiana (Fig. 8) - la relación entre la vida cotidiana y la acción de Dios. Los sarmientos de la vid seríamos nosotros (cristianos y judíos), que somos la viña del Señor. Grabar ve en los frutos, los animales y las labores de la tierra una tierra ideal que es regida por Dios. Algunos animales tienen un sentido particular: palomas bebiendo las almas que beben de las aguas paradisíacas. El pavo real - vida eterna (Fig. 13). El conejo comiendo uvas (Fig. 14) - símbolo de los placeres terrenales. Pájaro dentro o fuera de la jaula (Fig. 15) - alma dentro o fuera del cuerpo. En la opinión de la mayoría, el gran vaso de donde sale la fructífera vid (Fig. 16) o un árbol, evocaría automáticamente la idea de la vida, y sobre todo, vida eterna.

Entre los dos extremos (se resume todavia en el trabajo de Talgam), es decir, entre la opinión de los que en todo ven una alegoría y un símbolo y la de los que están acostumbrados a negar ya de entrada cualquier simbolismo, se da también un tercer camino intermedio: el de los que admiten que hay casos de simbolismo claro, y casos en que no existe tal simbolismo. En esta última categoria destacan los nombre de Dauphin y Piccirillo

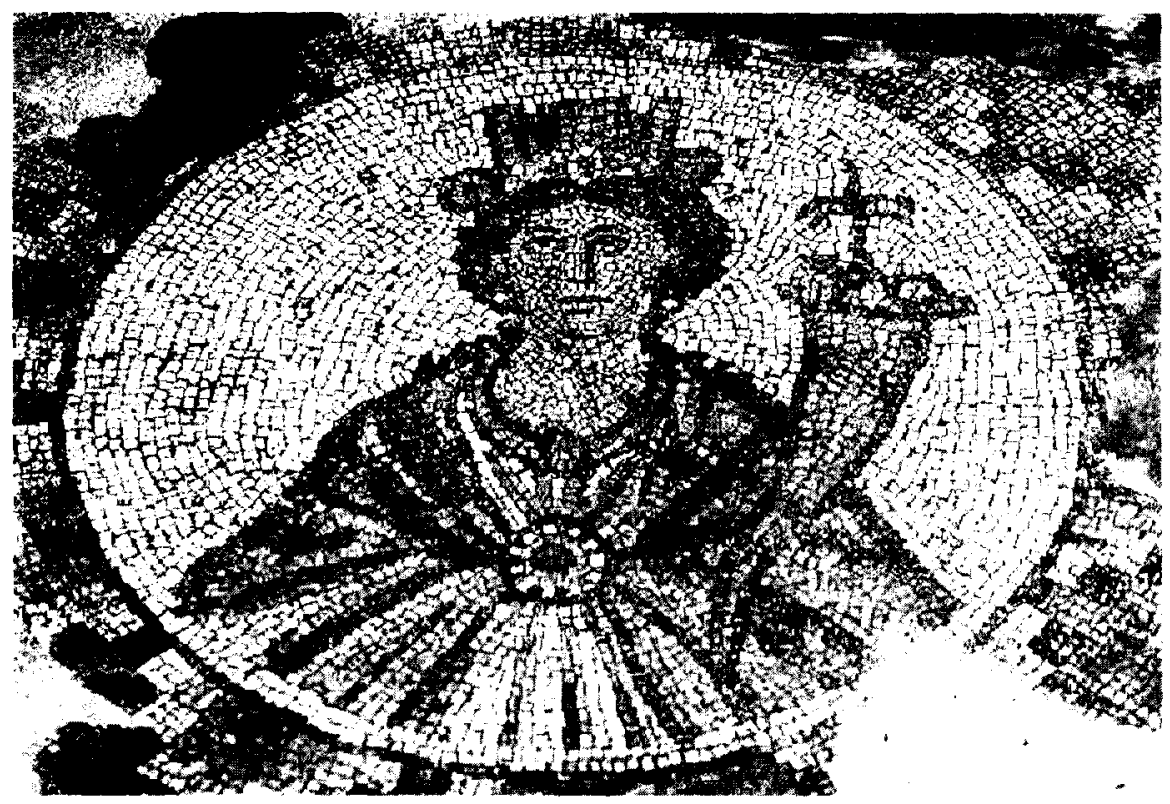

Fig. 12. Tyche. Bet Sheán (Biblical Archaelogy Review 16, 1990, pág. 30). 


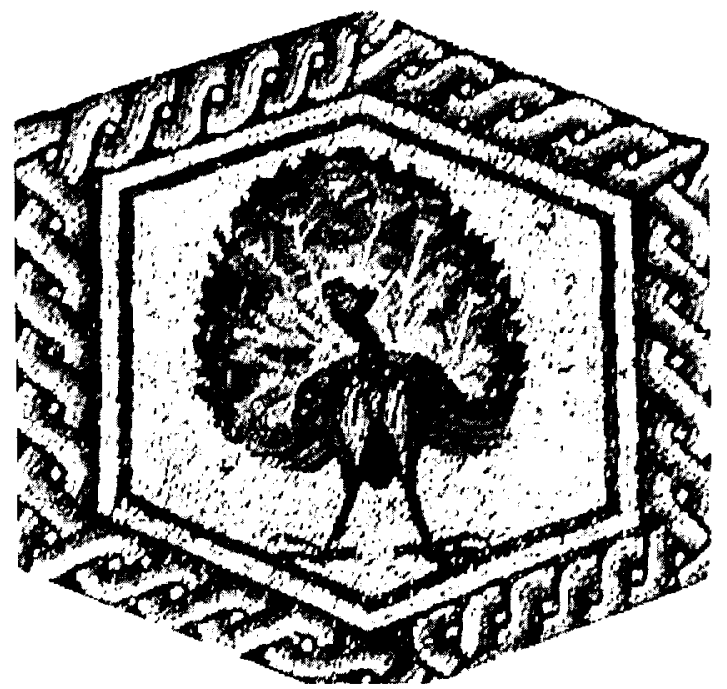

Fig. 13. Pavo real. Villa romana, Lod (Talgam 1988, cubierta).

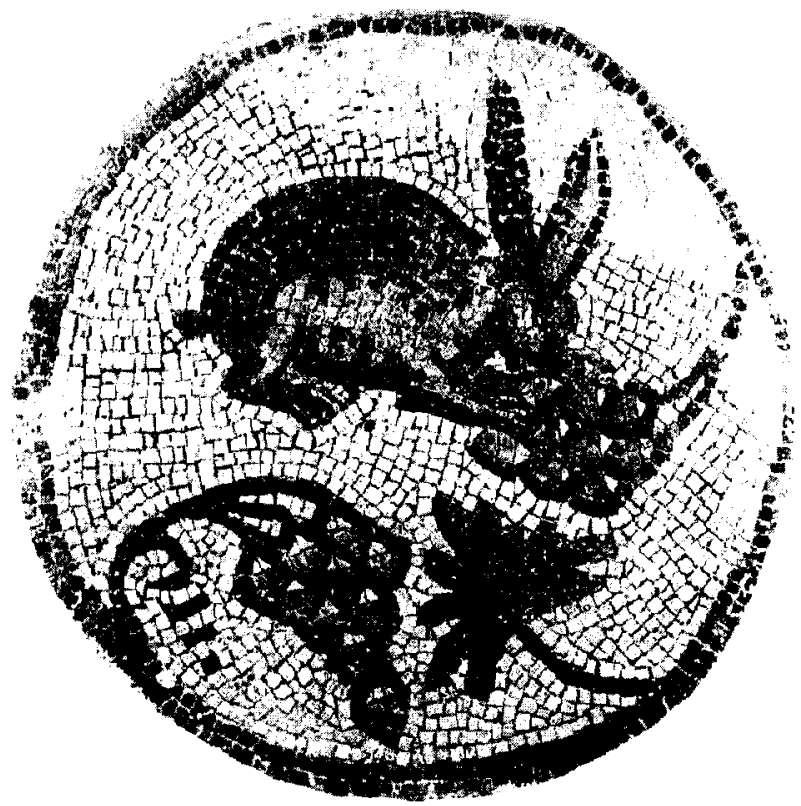

Fig. 14. Conejo comiendo uvas, capilla de Maria, Elias y Soreg, Gerasa (Piccirillo 1986a, pág. 229, fig. 17). 


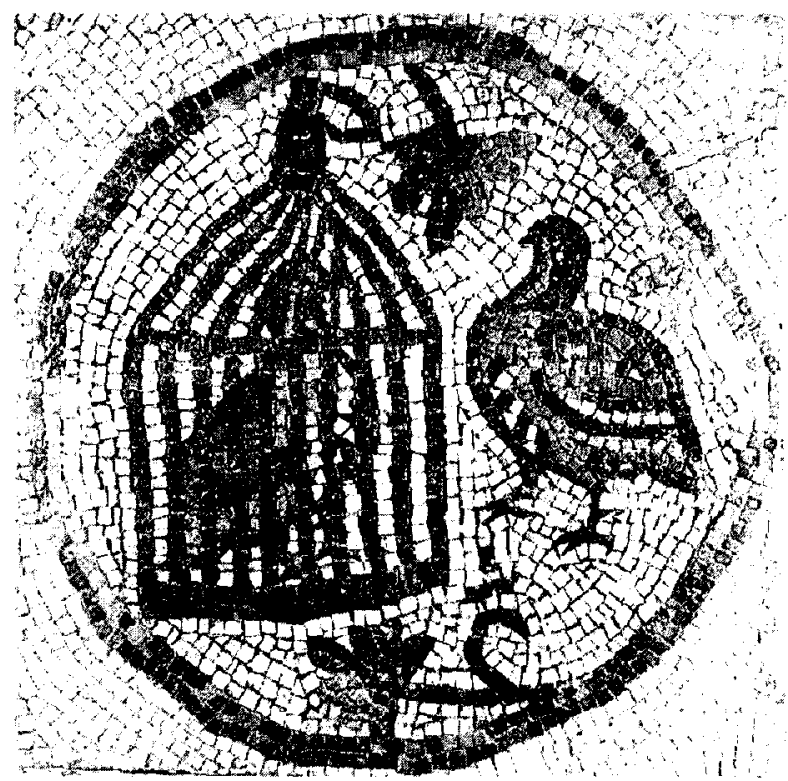

Fig. 15. Pájaros, capilla de Maria, Elias y Soreg, Gerasa (Piccirillo 1986a, pág. 229, fig. 18).

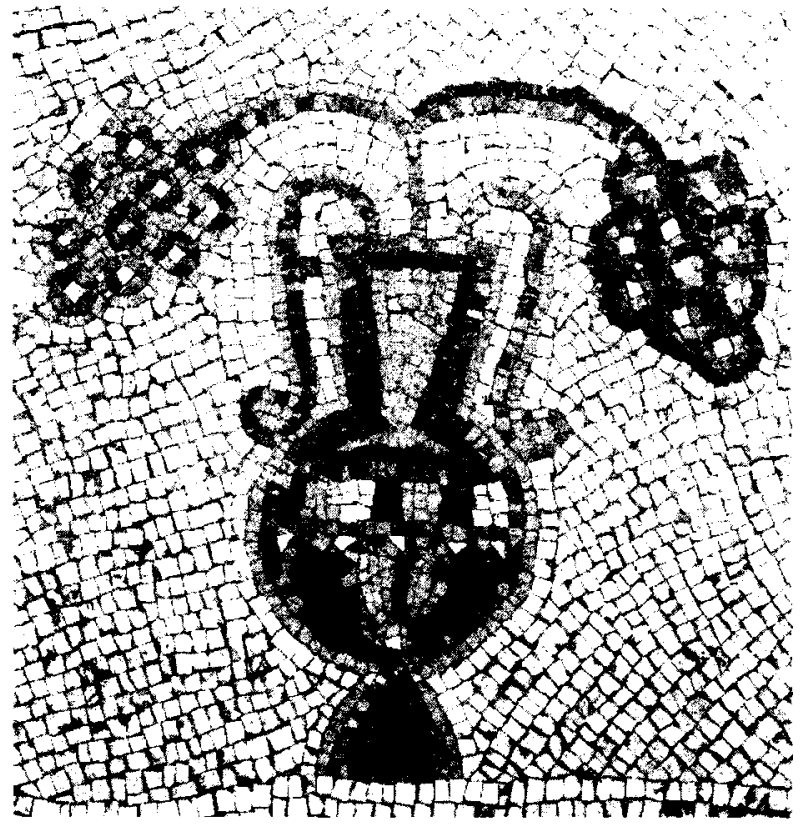

Fig. 16. Ánfora con uvas, capilla en Wadi Afrit, Monte Nebó (Piccirillo 1986a, pág. 243, fig. 39). 
para los mosaicos de Israel y Jordania, y los de Alföldi-Rosenbaum, WardPerkins y Dunbabin para los del Norte de Africa ${ }^{18}$.

\section{Nuestro trabajo}

En medio de esta gama de opiniones, que naturalmente podría detallarse mucho más, se impone la necesidad de un estudio más sistemático y profundo de los propios mosicos y de su aportación iconográfica. Pero lo más necesario, en nuestra opinión, es adentrarnos un poco más en el gran repertorio literario de la literatura patrística, que nos puede dar de por si la verdadera dimensión de hasta dónde llegaba en aquellos mismos días, y hasta en aquellas mismas regiones, el conocimiento de la literatura clásica por parte de los autores eclesiásticos (Basilio, Gregorio de Niza, Gregorio de Nacianzo, Juan Crisóstomo, entre los principales), el uso que de ella hacian en sus homilias y en sus comentarios biblicos, y la posible conexión entre su familiaridad con los temas mitológicos y la decoración de las iglesias contemporáneas. Trabajos de este tipo han sido ya realizados en parte por varios autores modernos, entre los que destacan los nombres de Rahner (1963) y de Maguire (1987). Siguiendo sus huellas y ensanchando las perspectivas, nosotros dedicaremos la primera parte de este trabajo a la presentación de los materiales patrísticos tal como los hemos recogido directamente de las fuentes. En la segunda parte, nos ocuparemos de la presentación sistemática de los mosaicos por temas, con los principales datos bibliográficos, y algun que otro apunte. La tercera parte, para la cual tenemos ya todo el material recogido, está redactada sólo parcialmente, y va dedicada al estudio particular de algunos de los temas más sobresalientes en los mosaicos, ya sea por su interés iconográfico, ya por la abundancia de comentarios textuales que sobre ellos hayamos podido recoger. La lista de los temas escogidos para esta tercera parte es la siguiente:

1. El agua

2. La tierra y sus frutos

3. La rueda del tiempo alrededer del dios sol

4. Ulises y las sirenas

\footnotetext{
18 Resumiendo los resultados de su estudio, Dunbabin define asi elementos simbólicos más generalizados: "The vine, the birds in Palestine, the deer drinking from the springs of life, the fish in the waters of baptism have become elements in a universal language; the mosaic's function is to evoke these concepts in a manner as ornamental as possible" (DUNBABIN, 1978: 195).
} 

5. Paisajes paradisíacos
6. Dionisos y su círculo
7. Orfeo
8. Las aves
9. Madre e hijo
10. Fedra e Hipólito

Desde el punto de vista geográfico, nuestro estudio se limita a cuatro paises del actual Oriente Medio: Israel, Jordania, Siria y Libano. Sin embargo, dado que algunas de las más importantes ciudades de la antigua Siria, tales como Antioquia, forman hoy parte de la actual Turquía, algunas regiones del sur de este último país también se han incluido. Lo mismo hay que decir de una pequeña parte de la antigua Palestina, esto es, la región de Sheikh Zuweid en la costa del norte del Sinaí, así como el monasterio de Santa Catalina del Monte Sinaí, regiones que se encuentran hoy día bajo la administración de Egipto.

En cuanto a límites cronológicos, hemos fijado el terminus a quo en la época de Constantino el Grande, esto es, en el primer cuarto del siglo IV d.C., extendiendo el terminus ad quem hasta la última fecha registrada en los mosaicos cristianos de Jordania, que es el AD 785 (Piccirillo 1987:185$186)$, unos ciento cincuenta años después de la conquista musulmana de Oriente.

A pesar de que nada tenga que ver con los resultados del estudio, queremos precisar que este trabajo quiere representar un solo capítulo de una investigación mucho más amplia en su finalidad, que incluiría el tema completo del paganismo en el país de Israel durante el periodo clásico, esto es, el que va desde la invasión griega de Alejandro Magno en el 332 a.C. hasta la invasión musulmana, que finalizó en el AD 640.

\section{Actitud de los Padres de la Iglesia ante la mitologia}

Es ya conocida la paradójica posición de los Padres de la Iglesia, y en particular de los orientales, en cuanto a su opinión sobre la mitología pagana. Por una parte, no se abstienen de prevenir a los cristianos, a sus oyentes en las homilías en la iglesia, y a los lectores de sus obras teológicas y exegéticas, del peligro que corren de caer, por pura inercia de la vida cotidiana, en los escollos del paganismo que todavia les rodeaba. El arte, la literatura, los modos de hablar de la gente, estaban He- 
nos de alusiones a hechos y personajes de la mitología griega, y de expresiones tomadas directamente de los atributos de los dioses. Habían pasado a ser patrimonio de todo el mundo civilizado e incluso del no civilizado, esto es, más típicamente oriental, que poseía su propia mitología, solamente en parte absorbida en la del pueblo helénico que les había estado dominando por varios siglos. Era pues, deber de los educadores cristianos, ayudar a sus creyentes a desprenderse de este engorroso bagage pagano y adquirir en su lugar la costumbre de ver en las verdades cristianas las únicas causas aceptables de los hechos y de los fenómenos de la naturaleza. Por otra parte, esos mismos maestros, a los que llamamos Padres de la Iglesia, estaban ellos mismos tan apegados al modo de pensar y de expresarse tradicionales paganos, que sus escritos contienen infinidad de alusiones directas e indirectas y de expresiones bien claras a todo aquel mundo pagano al que ellos habian renunciado. Algunos de ellos, no sólo no sabían desprenderse de tales alusiones cuando llegaba el momento de expresarse con una retórica algo elevada ${ }^{19}$, sino que argumentaban incluso de manera positiva sobre el problema, justificando el uso de expresiones paganas para hacerse comprender mejor por el público pagano, como Clemente de Alejandría. Quería describir los misterios cristianos usando las mismas fórmulas a que estaban acostrumbrados los adeptos a las religiones mistéricas de su tiempo, según confiesa él mismo ${ }^{20}$. El propio Clemente parece casi hacer ostentación de su exacto conocimiento de la mitología pagana cuando se complace en enumerar con sorprendente precisión sus personajes y elementos delante de los que estaban ya dispuestos a aceptar la fe cristiana ${ }^{21}$.

19 En la muerte del gran Basilio, su amigo Gregorio Nazianzeno pronunció un elogio fúnebre en el que no dudó en usar multitud de imágenes paganas, diciendo, por ejemplo, que los cristianos, después de la muerte "se hunden bajo tierra» y "descienden al Hades". El mismo Gregorio llama a la tumba de su joven primo "el lugar elíseo" y añade que «Eros no había todavia alumbrado la antorcha para su cámara nupcial." Las Gracias y las Musas, que él introduce conversando sobre el cuerpo de aquel mismo joven, juraban que jamás crearian una estatua como él entre los hombres, esto es, que nunca volverían a crear un hombre como él (SEVCENKO, 1980: 57).

20 "Os daré el conocimiento de los misterios del Logos por medio de imágenes que os son familiares... Venid, que os voy a mostrar al Logos y los misterios del Logos, y os los daré a comprender por medio de imágenes que os son familiares" (Protréptico XII, 119, 1). Véase RAHNER 1963: 11-12.

21 De su Cohortatio ad Gentes, X (PG 8, 217-220) es el siguiente pasaje, particularmente importante para nuestro propósito: “¿Por qué, pues, oh hombres, creéis que Mercurio sea Tifón, y Andócido y Amieto? ¿Tal vez hay quien no sepa que aquelios son rocas, al igual que el propio Mercurio? Del mismo modo ni el halo es dios, ni el arco iris, sino que son unos cambios del aire y de las nubes. Al igual que tampoco deben contarse entre los dioses al día, ni al mes, ni al año, ni lo que con ellos se completa, el tiempo (Kairos). Y asi ni al sol (Helios), ni a la luna (Selene), por los cuales se definen todas aquellas cosas que ya mencionamos. ¿Qué persona sana va a creer 
Otras veces, como en el caso de Eusebio de Cesarea, hacen un esfuerzo por buscar un escondido sentido teológico en las explicaciones filosóficas de Platón cuando usaba figuras mitológicas para expresarse. Fue Eusebio quien tuvo la idea de escribir un tratado entero sobre lo que llamaba la "Preparación Evengélica". Su tesis fundamental es que las principales verdades teológicas que habían sido o habrían de ser reveladas a los hombres en las Sagradas Escrituras, habian sido ya enseñadas a los pueblos paganos, aunque escondidas bajo el ropaje de la filosofía y la mitología griegas. Pero al mismo tiempo quiere dejar bien claro a sus lectores lo falso de las tradiciones mitológicas heredadas por los propios filósofos, que él mismo conoce a la perfección ${ }^{22}$.

Lo interesante del caso es ver el profundo conocimiento que los Padres tenían de las tradiciones mitológicas paganas de que se reían y del modo de pensar de los filósofos paganos que criticaban. Incluso el propio Cirilo de Jerusalén, del que se han conservado las homilias mistagógicas, destinadas a la preparación de los catecúmenos que iban a ser bautizados en la noche de Pascua, se sentía obligado a repasar delante de ellos, hasta hacía poco paganos, las materias y los personajes mitológicos que formaban parte del panteón griego-romano para hacerles ver lo ridículo e ilógico de la fe que acababan de abandonar ${ }^{23}$.

que sean dioses el juicio, el castigo, la justicia, la venganza? Como tampoco las furias (Erinnyes), las parcas (Moirai), el destino (Eimarmene). Ni tampoco la república, la gloria, ni Plutón, al que los pintores reproducen ciego, deben de ponerse en el número de sus dioses. Pero si tenéis ya por dioses al pudor (Aido) y al amor (Eros), y a Afrodita, que lo sean también la infamia (Aischyne), y la libido (Orme), y la belleza (Kallos) y el coito (Synousia). Tampoco tendréis razón en tener por dioses gemelos al sueño (Hypnos) y la muerte (Thanatos), puesto que son cambios que ocurren por naturaleza a los seres animados. Tampoco es lógico que llaméis dioses a la fortuna (Kera), al destino y a las parcas. Y si la contención (Eris) y la lucha (Mache) no son dioses, tampoco deberian ser dignos de tal nombre Ares y Enyo. $Y$ si negáis que los relámpagos y los rayos y la lluvia sean dioses, ¿por qué ponés en su número al fuego (Pyr) y al agua (Hydor)? Y ¿por qué también a las estrellas fugaces o cometas, que nacen de cierto cambio atmosférico?"

22 Ya en el título al cap. 14 del Libro XIII de su Praeparatio Evangelica leemos: "Que Platón no fue feliz en todos sus dichos; también, que no es sin causa que hayamos rechazado su filosofía... [citando a Platón, Tim. 40 d 6 - 41 a 3]. Asi pues, admitamos y digamos según ellos la genealogía de estos dioses: Gé y Uranos tuvieron por hijos a Océano y a Tethys; estos: Phorcys, Cronos y Rhea; Cronos y Rhea: Zeus, Hera y todos aquellos a quienes sabemos que se llamaba hermanos de ellos, con sus descendientes." La inconsecuencia se hace sentir todavía más en lo que luego cita de Platón en su República: "Son... las que nos contaban Hesíodo. Homero y los demás poetas; puesto que eran ellos los que componian esa fábulas mentirosas que luego contaban y todavía cuentan a los hombres... Que en esas ficciones se representa a los dioses y héroes de una manera errónea, como cuando un pintor hace cuadros que en nada se parecen a los objetos que pretende representar..." (por ejemplo el hecho de Afrodita y Ares, atrapados por Hefaistos)..." (Eusebio de Cesarea, Praep. Evang. XIII, 3, 1-2).

23 «... la madera, ...el gato, el perro y el lobo son adorados en lugar de Dios: y la culebra y el dragón... Incluso (me da vergüenza, pero lo diré), incluso la vid es adorada por algunos. El vino ha sido dado para alegrar el corazón del hombre: y Baco es adorado en vez de Dios. Dios creó el 
En algunos Padres, la enumeración que hacen de los misterios y de los cultos paganos es tan detallada y precisa, que uno puede preguntarse si no trataban ante todo de impresionar a los oyentes con su erudito conocimiento del mundo profano. Al fin y al cabo habían estudiado en las mejores escuelas de retórica, y no hay duda que sabían ganarse la atención de sus oyentes. Uno de los pasajes más impresionantes es el de Gregorio Nazianzeno en su homilía para el día de la Epifania. En ella enumera uno por uno no sólo los mitos principales del panteón griego, no olvidándose de mencionar y describir sus ritos y sus cultos más alejados de la espiritualidad cristiana, sino que también pasa revista a los más importantes misterios frigios, egipcios y caldeos ${ }^{24}$. Por cierto que este texto contiene algunas referencias directas a temas que fueron por la misma época representados en la decoración musiva de las iglesias, tales como el río Nilo, que serán oportunamente traídas a colación en el estudio detallado de los motivos alegóricos.

Este conocimiento profundo de la cultura pagana que muestran los escritores eclesiásticos de la época, sobre todo de los siglos IV y $V$, no era en modo alguno a sus propios ojos una ofensa a la fe cristiana y a la teología que pretendian poseer. Al contrario, una y otra vez se nos hace percibir la satisfacción que les daba poder hacer uso de tal conocimiento, ya fuera para atacar de frente a las falsas doctrinas paganas, ya para usar de él como cantera de material pedagógico. A veces, son ellos mismos los que así lo valoran. Como en el caso de los Padres de Capadocia, y sobre todo Gregorio de Nisa ${ }^{25}$. No considera aquella cultura como un estorbo a la fe cristiana, sino, al contrario, como una aportación importante para la comprensión de sus misterios.

\section{La interpretación de las escenas mitológicas en los Padres de la Iglesia}

Es evidente que los Padres de los siglos III, IV y $\mathrm{V}$ no fueron los inventores de una interpretación simbólica o alegórica de la mitología para

\footnotetext{
trigo... para que el pan fortaleciera el corazón del hombre. Pues ¿por qué es Ceres adorada? El fuego se produce por la fricción de las piedras hasta el día de hoy: ¿como puede pues ser Vulcano quien inventara el fuego? Me callo las transformaciones de Júpiter en cisne... en toro... Su dios de los griegos fue atrapado en adulterio, y no les da vergüenza; puesto que, si es adúltero, no le llamen Dios..." (CIRILo de Jerusalén, Cathechesis VI. De Deo uno, PG 33, 553-55).

24 Gregorio Nazianzeno, Oratio 39, PG 36, 336-341

25 "Conviene pues abandonar el sentido literal por el sentido espritual y ver en eso una orden de la Escritura a los que buscan la libertad por la virtud. E igualmente protegerse con las riquezas
} 
servirse de ella con fines pedagógicos. Clemente de Alejandría declaraba ya que tanto griegos como bárbaros habian tradicionalmente envuelto la enseñanza de los temas religiosos con un lenguage metafórico que más bien ocultaba que revelaba los misterios divinos ${ }^{26}$. Los Padres la habian aprendido sobre todo de los filósofos de la escuela neoplatónica de la academia de Alejandría. En ella se habrian formado incluso representantes de religiones diferentes que la pagana, como el judío Filón a principios del siglo I, de cuyo sistema exegético aprendieron luego los maestros cristianos de la misma ciudad de Alejandría, tales como Orígenes ya dentro del siglo III, y luego el propio obispo Clemente y tantos otros. Pero todavía en la segunda mitad del siglo IV seguían en pie en Siria escuelas filosóficas neoplatónicas tan importantes como la de Apamea, que justamente en esta época parecen haber ampliado el campo de sus disciplinas a la retórica y artes liberales en general (Balty 1995: 45). Fue en tales ambientes donde el joven emperador Juliano se había convencido de la necesidad de volver a las raíces paganas, argumentando contra una visión tergiversada del paganismo por parte del cristianismo por desconocer o rechazar la interpretacón auténtica y profunda, esto es, alegórica, de los mitos.

Filón de Alejandria habia aplicado a la exégesis bíblica los principios de la interpretación alegórica, lo que le permitía poder presentar delante del mundo pagano que le rodeaba una visión muy mitigada de todo lo que podía ser ofensivo tomado literalmente, como el precepto de la circuncisión corporal. Su intento era el de dar un método de elevación mística a sus propios correligionarios, a partir de leyes que ya no tenían apli-

de la cultura profana en la que los paganos tienen ventaja, como la filosofia moral y la filosofia de la naturaleza (ten gar éthniken te kai physiken philosophian), la geometria y la astronomia, la dialéctica y todas las demás ciencias cultivadas por los paganos: nuestro guia nos ordena quitárselas como prestadas a los egipcios que las posseen como siendo útiles dado el caso, cuando es neceario adornar el santuario divino de la revelación con los tesoros de la inteligencia. En efecto, vemos que los que han puesto la mano sobre ese botin se lo llevan a Moisés, cuando trabaja en el Tabernáculo del Testimonio, aportando cada uno su contribución para la edificación del santuario. Vemos que esto se efectúa todavia en nuestros días: muchos llevan en ofrenda a la Iglesia de Dios su cultura profana (ten exo paideusin). Como el gran Basilio, quien, después de haber acumulado en su periodo juvenil los más bellos tesoros de Egipto, los consagró a Dios para que sirvieran de ornamento al tabernáculo verdadero, que es la Iglesia" (GREGorio DE NiSA, ed. Daniélou, Paris, 1987, p. 174). Cosa semejante dice el mismo Padre en su panegírico de Gregorio Taumaturgo, quien precisamente con su cultura helenística podía refutar los errores de griegos y paganos y asi traerles al reconocimiento de la verdad cristiana (GAEgORIO DE NISA, De Vita S. Gregorii Thaumaturgi, PG 46, 901).

26 «... De modo que todos aquellos que trataron de las cosas divinas, tanto los bárbaros como los griegos, ocultaron los principios de las cosas, y comunicaron la verdad con enigmas, signos y simbolos, alegorias y metáforas, y con todo un sistema de modismos y convenciones" (Clemente de AlejandriA, Strommata V, 4, PG 9, 39-46. 
cación ninguna en la vida real del judío alejandrino ${ }^{27}$. $Y$ de los mismos principios se sirvieron desde el comienzo los escritores cristianos orientales, tales como el autor de la célebre Epístola de Barnabé ${ }^{28}$. En cuanto a exégesis bíblica, los escritores de los siglos posteriores no hacian más que continuar la tradición, aunque no existe una línea de pensamiento que se pueda aplicar a todos, ni mucho menos. E incluso los que aprendieron en Alejandría la interpretación alegórica de la Biblia no se muestran consecuentes consigo mismos. El propio Basilio, quien, al decir de su amigo Gregorio de Nisa habia hecho, con aquella cultura clásica, su gran contribución a la Iglesia, como vimos, tiene frases de rechazo directo de aquel sistema interpretativo, lo cual es bastante singular ${ }^{29}$. Pues, dada la ocasión, esta misma estima del valor semántico primario de los términos, le lleva a usar alguno de ellos en un sentido que es totalmente profano, cuando ya el mismo término habia sido consagrado por un uso cristiano con matices muy diferentes, que él no podía en manera alguna desconocer ${ }^{30}$.

Pero no todos reaccionaban de igual manera ante la posibilidad de la interpretación alegórica, tanto de hechos como de expresiones. Eusebio de Cesarea, por ejemplo, aprovecha tal interpretación para enseñar que la revelación había sido dada ya a los griegos antes de la predicación cristiana, a través de sus poetas y filósofos, que sin duda habían conocido las Escrituras hebreas. Y así expone su teoría de que ya Platón, con palabras alegóricas, refiere el mismo relato que Moisés en la Biblia sobre la

\footnotetext{
27 Así, por ejemplo, la alegoría de las seis ciudades de refugio (núm. 35), que se interpretan como una serie de estaciones en el camino hacia Dios, situadas como están a una y otra parte del río, esto es, que son en parte accesibles y en parte inaccesibles al alma (Fug. 86ss.).

28 Es conocido su sistema interpretativo, que llegaba a ridiculizar injustamente delante de un público cristiano un rito tan fundamental para la religión hebrea como el de la circuncisión, a base de proponer una pura lectura alegórica de las leyes bíblicas que lo prescribian

29 "Conozco - dice en un pasaje muy explícito - las leyes de la alegoria, no por haberlas imaginado yo mismo, sino por haberlas encontrado en obras de otros. Los que no aceptan escuchar las Escrituras en su significado común, afirman que el agua no es agua, sino cualquier otra sustancia; las palabras: plantas, peces, las interpretan como bien les parece... En cuanto a mí, cuando oigo hablar de hierba, pienso en la hierba; y lo mismo hago con planta, pez, animal salvaje, animal doméstico. Me tomo todas las cosas tal como se dicen. Puesto que no me avergüenzo del Evangelio" (BASILIO, Homilia sobre el Hexaémeron, IX, 1, ed. Giet, Paris, 1968, págs. 478-481).

30 Es así como en su descripción de la primavera, Basilio emplea el término griego hesechia, no en el sentido filosófico de "tranquilidad de espíritu", ni en el sentido con que, derivado de éste, lo usó luego toda la tradición oriental, que lo consagró en la virtud básica del monje. Basilio se refiere con aquel término a la tranquilidad tan deseada por el habitante de la ciudad, de poder sentirse finalmente libre de la gente que constantemente le rodea (BASILIO, Epistola 14, ed. Deferrari, Londres y Cambridge Mass., 19??, I, págs, 106-111). Sevcenko, que cita este texto, hace notar que Dios es mencionado sólo dos veces en todo el escrito.
} 
creación del hombre y el Paraiso terrenal ${ }^{31}$. Eusebio no se explicaba lo que él entreveía en los escritores profanos más que por plagio consciente de las Escrituras. Su ciencia, por otra parte, era un mero reflejo deforme de la sabiduría hebrea y de ningun modo llegó a la perfección de la revelación cristiana.

Los había, como Metodio de Olimpo, que no dudaban en ver a Jesucristo en persona bajo la figura mitológica de Beleforonte y al dragón del Apocalipsis en el monstruo de la Quimera. Esta, afirma sencillamente Metodio, fue decapitada por Cristo (Sevcenko 1980: 57) ${ }^{32}$. Pero generalmente los Padres no iban tan allá, y es difícil poder valerse de ellos como si de una manera explícita hubiesen interpretado los mitos griegos en un sentido que era válido para los cristianos.

En cambio, su familiaridad con tales mitos y con las alegorias de los elementos naturales era tan grande, que en sus descripciones no diferían prácticamente de los escritores paganos contemporáneos. Gregorio Nazianzeno, por ejemplo, además de la homilía antes mencionada, predicó en el domingo siguiente al de Pascua otra homilía en la que hizo una interesante ékfrasis de la primavera, a la que llama "reina de las estaciones", con innumerables detalles sobre los trabajos del campo, los pájaros, la miel, el río, las fuentes, las ovejas, los delfines, los caballos y las abejas. Casi idéntica a su descripción es la que tenemos de Libanio, el escritor pagano amigo del propio Gregorio ${ }^{33}$. Vale la pena recordar que, tanto aquellos mismos elementos naturales en su máxima espontaneidad y belleza, como la propia primavera, representada en personificación alegórica, son frecuentes temas de los mosaicos que adornaban los pavimentos de las iglesias del tiempo ${ }^{34}$.

La familiaridad con que algunos de los Padres nos sorprenden refiriéndose, totalmente a sabiendas, a los temas de la mitología, la revelan a

31 "Acerca de la fe de ciertas tradiciones inefables, Moisés relata que al principio de la creación del mundo hubo un cierto paraiso de Dios, en el que el hombre fue engañado por la mujer a instigación de la serpiente. Ahora bien, oye lo que a su vez Platón, transponiendo casi literalmente sus expresiones, puso en su Banquete en alegoría: el paraíso de Dios pasa a ser el jardín de Zeus...; en vez de decir en qué momento nuestro mundo fue creado, su expresión "el día en que nació Afrodita" “lo designa alegóricamente, expresando su belleza..." (EUSEBIO DE CESAREA, Praeparatio Evangelica, XII, 11, 1-2, ed. Des Places, 1983, París, págs. 68-70).

32 Este texto, como hace resaltar Sevcenko, es importante para la interpretación cristiana del mosaico de Hinton St. Mary, Inglaterra, donde además de Belerofonte está también la figura de Jesús.

33 Gregorio de Nazianzo, Oratio 44, PG 36, 617-620. Weitzman (1951) hace notar que en la descripción de la primavera de Libanio se añade también el despertar sexual de los animales en esta época del año.

${ }_{34}$ Véase más adelante, cuando tratemos del sol, Helios. 
veces los filósofos cristianos cuando aluden a veces a temas semejantes, aunque de un modo espontáneo, y tal vez sin percatarse de lo poco cristiano que eran sus expresiones. Así por ejemplo, cuando el filósofo Eneas, según Teofrasto, dice que "una cierta fortuna (tyche)" le vino en ayuda en el momento preciso ${ }^{35}$.

A pesar de todo lo dicho, la crítica de los maestros cristianos contra los mitos y los cultos de la fe pagana era, por lo general, tan áspera, que no aceptaba ninguna clase de paliativo que pudiera hacerlos aceptables: «...¿ ¿No es esto - decía Gregorio Nazianzeno- lo que ceiebran los griegos? Para mí, todas sus ceremonias y misterios no son más que invención tenebrosa de los demonios, ficción de una mente descarriada, apoyada en el tiempo y disimulada por el mito. Ya que lo que adoran como verdadero, lo envuelven ocultándolo como mito. Mejor sería que, si lo que predican es verdad, que no lo llamasen mito sino que lo mostrasen, para justificarse contra cualquier acusación de vergüenza y obscenidad" ${ }^{36}$.

De la tal crítica a no aceptar la transformación de los mitos en alegorías, la distancia era muy corta. $Y$ es natural que veamos expresiones de rechazo directo de un uso alegórico de los mitos, aunque justificando el sistema alegórico en general. Así se expresaba el mismo Gregorio, por ejemplo, en uno de sus discursos contra Juliano el Apóstata: "También tenemos nosotros ciertas afirmaciones que contienen un significado escondido. No quiero negarlo. Pero ¿en qué consiste el modo y el sentido de su doble significado? La forma externa no es impropio y el significado escondido es maravilloso, sublime y magnífico para aquellos que están penetrados de su profundidad y, como un cuerpo de belleza inasequible, no está envuelto en un vestido feo. En mi opinión, es necesario que ni el modo de expresar ni las apariencias de las cosas divinas sean impropias o indignas de lo que manifiestan, ni que sean tales que incluso las personas se ofenderían si fuesen referidas a ellas. Al contrario, tienen que tener la máxima belleza, o evitar al menos un exceso de fealdad, para que complazcan a los sabios y que por otra parte no dañen a la masa" ${ }^{37}$.

Y para que no caigamos en la ilusión de ver en toda representación del mítico poeta Orfeo una imagen de Cristo, vale la pena leer ese otro pasaje del mismo Gregorio en la misma diatriba contra Juliano: "Que venga

35 PG 85, 873. En una nota a pie de página, el editor de ese texto nos recuerda que aquel tipo de expresiones se encuentran con mucha frecuencia, no solamente en las obras de los sofistas del tiempo sino también en las de algunos de los Padres, como por ejemplo San Basilio.

36. Gregorio Nazianzeno, Oratio 39, PG 36, 337.

3) Gregorio Nazianzeno, Contra Juliano, Oratio IV, 118. 
Orfeo con su cítara y con aquel canto que todo lo revuelve y que haga resonar en honor de Zeus las grandes y sublimes palabras y los pensamientos de la teología: "Oh Zeus gloriosísimo, altísimo entre los dioses, que te rodeas de estiércol, sea de ovejas, de caballos, o de mulos". Con lo cual se demuestra, creo yo, la fecundidad y la fuerza vital del dios" $Y$ Gregorio continúa su burla con otro verso de Orfeo en el que demuestra la desvergüenza de Afrodita, para terminar con estas palabras: "Sean traídas a escena esas cosas, una tras de otra, ante los admirables oyentes de esta teología, y que vayan después a buscarles unas extravagantes interpretaciones alegóricas...» 38 .

De tomarlos como pauta general, ejemplos como ese último parecen echar por tierra las interpretaciones que algunos estudiosos modernos parecen haber encontrado en los mitos paganos representados todavía en los mosaicos de la época que nos ocupa, tanto en el norte de Africa como en Siria y Palestina.

\section{Decoración figurativa y opiniones contradictiorias}

Que en el siglo VI era todavía común el uso de figuraciones mitológicas que debian interpretarse en sentido alegórico no sólo lo sabemos por los pavimentos de mosaico que han llegado hasta nosotros, sino también por algunas descripciones literarias. Conocidas son las del retor Juan de Gaza, quien describió con mucho detalle la gran bóveda de la sala principal de unas termas públicas de su ciudad, que nos dice hasta qué punto el público intelectual y el sencillo apreciaban las imágenes alegóricas tradicionales del cosmos, el tiempo y el espacio, fuerzas ahora sometidas y dirigidas únicamente por un Dios único que ha operado ya la redención cósmica, simbolizada por la cruz central ${ }^{39}$.

\footnotetext{
8 ibid., 115.

39 He aquí como detalla Lehmann la reconstrucción visual hecha por G. Krahmer de la pintura de Gaza: “Un curioso despliege de elementos astronómicos tales como el sol y la luna, el globo terrestre, y Ortros, que incluye también a Fósforo y Hespero, las únicas estrellas del tolo de Varrón. El símbolo cruciforme de la tradición cristiana, que aparecía ya en calidad de estrella guiadora en el palacio de Constantino, ocupa el lugar más alto. Los dioses paganos e incluso los planetas han sido eliminados. Sólo se han conservado los elementos del tiempo y del espacio y las fuerzas de la naturaleza: Aion, Aurora, las Estaciones, las Horas, Anatolae y Nyx simbolizan el movimiento en el tiempo; Océano. Thalassa, Ge, Europa, Asia y Uranós ilustran el espacio cósmico; los Vientos, Tempestades, Lluvias, Relámpago, Rayo y el Arco Iris aparecen como las fuerzas elementales de la naturaleza. Fénix se refiere a la eterna renovación de la vida, mientras que Sabiduria y Virtud están acopladas con la fuerza corporal de Atlas para sostener el globo solar de luz, que es a la vez físico e intelectual. Y en lo alto, cerca de la cruz, un grupo alegórico de
} 
En pleno siglo VI, entre el gentío cristiano de Gaza que disfrutaría diariamente de los baños públicos, pocos serian los que se preguntasen sobre la relación que pudiera existir entre aquellas figuras alegóricas que estaban representadas sobre sus cabezas y su propia fe o su propia vida. Los paganos, por su parte, que todavía los habría en gran número en la cosmopolita ciudad, tampoco harían mucho caso de la cruz central, que podía causarles molestia verla entre las figuras alegóricas tradicionales. $\mathrm{Ni}$ a unos ni a otros les importaría demasiado el tipo de decoración escogido para aquel lugar público, pues es evidente que había una aceptación general, no cuestionada, de la cultura tradicional ${ }^{40}$. Es a nosotros a quienes incumbe hacer un poco de ejercicio mental a fin de asumir la realidad de un contexto histórico que tanto difiere del nuestro, y aceptar que a la gente del tiempo les era más fácil entender el significado alegórico de las figuras míticas tradicionales. El propio Coricio de Gaza tiene también frases muy significativas en cuanto a la creencia popular que podía todavía sostener fábulas menos conocidas: "Quizás hayáis visto en vuestro país el pino, y si éste era originariamente una muchacha - puesto que así cuentan algunos esta historia-, de como Bóreas, llevado por los celos del amor estaba por matarla, cuando Tierra, apiadándose profundamente de su súplica, envió un árbol del mismo nombre que la muchacha. Yo, ni me creo a los que lo cuentan ni tampoco es mi intención contarlo, sino que solamente quería decir que (dicho árbol) produce un fruto que se llama la piña..." ${ }^{41}$.

Evidentemente, la actitud de los Padres de la Iglesia hacia la decoración figurada en las iglesias es la que ve en aquella principalmente un medio de instrucción, actitud que, pasando por toda la Edad Media, continuará hasta el día de hoy. Pero en los pocos textos que nos han quedado de aquella época, no se excluye tampoco el valor estético de las formas y figuras, empezando por la arquitectura y terminando por los mosaicos del pavimento. Es así que Gregorio de Nyssa se expresa muy explícitamente en un sermón en honor de San Teodoro mártir, pronunciado en su propio martyrium. Pero lo que más le gusta es subrayar el lado descriptivo de las imágenes, las escenas del martirio del santo, y «la forma humana de

Cosmos triunfando sobre Fisis y coronado por Eter resume la ideologia de base..." (LEHMANN 1945: 23 and Fig. 63 [por Krahmer])

40 Es nuestra convicción que esta misma seria la verdadera actitud del Rabán Gamaliel al aceptar que, en el Baño de Afrodita que él solía frecuentar en Aco, hubiese una estatua desnuda de la diosa (MISHNA, Avodá Zará 3, 4). La respuesta dada por él a los que le preguntaban la razón de su comportamiento (que era ella quien se había introducido en sus dominios, y no al revés) fue rnás bien retórica y condicionada. No se daría hoy probablemente tal actitud en el rigido judaísmo ortodoxo.

${ }^{41}$ Coricio, En honor de Marciano., II, 42 (SMITH, 1978: 156). 
Cristo, que preside la lucha, pintándolo todo para nosotros como en un libro abierto que contiene traducciones de lenguas". Las pinturas, dice, adornan el templo como un prado ameno y florido, hablando desde el muro, con gran provecho. Pero también el mosaísta realizó una obra digna de aquella historia en el pavimento que es pisado por todos ${ }^{42}$. Ojalá que Gregorio hubiese sido un poco más explícito y nos hubiera descrito, con el mismo detalle que las pinturas murales, lo que estaba representado en el mosaico del suelo. Ni tan sólo nos dice si el mosaico, que tanto podía ser figurativo como simplemente geométrico, se refería en algún modo al tema del martirio.

En todo caso, existe un texto patrístico sobre las decoraciones de iglesias de mártires con escenas no directamente religiosas. Es la ya conocida carta escrita por Nilo, monje del Sinai en el siglo v, respondiendo al prefecto de provincia Olimpiodoro. El tema principal de tales escenas era nada menos que el tan conocido de las venationes o cazas, que en el presente caso llenaban tanto los muros laterales de la iglesia como el pavimento de mosaico. Animales de todo género se daban a la fuga ante el ataque de los cazadores con sus perros, peces de todas clases eran traídos a tierra firme por pescadores que les habian echado sus redes. Además, toda la iglesia estaba llena de cruces entre un sinnúmero de imágenes de animales y de plantas de todo tipo. Nilo encuentra muy pueril que de tal modo se quisiese distraer la mirada de los fieles. Una sola cruz debía verse, vueltos hacia oriente. Las pinturas tendrian que describir escenas del antiguo y del nuevo Testamento para instrucción de los analfabetos y los que desconocían las Escrituras. Las escenas gloriosas de los siervos de Dios ayudarian así a todos a preferir el cielo a la tierra, y las cosas invisibles a las visibles ${ }^{43}$.

\section{CONCLUSIÓN}

No podemos más que lamentar la poca literatura contemporánea que tenemos sobre el tema, aunque la que nos queda es bastante explícita como para mostrarnos la diversidad de opiniones que convivian ya en aquella época. Por lo demás, vale la pena fijarnos en el hecho de que desde nuestra perspectiva moderna, no podemos apreciar debidamente ni las intenciones ni la carga de simbolismo con que los artistas bizantinos

\footnotetext{
42 El texto griego dice textualmente: kai ho ton psephidon synthetes, historias axion epoieses to patoumenon edaphos (GAEGonIO DE NYSSA, Oratio laudatoria Sti. Theodori, PG 46, 737-740).

43 Nilo Sinaita, Epistolarum Lib. IV, 61, PG 79, 577-580.
} 
quisieron representar sus figuras, escenas y alegorías. Es lo que ilustra Haldon (1990:420) con un par de ejemplos. El primero es la expresión de Nilo Escolástico, del siglo vi, quien decía que cla imagen de un ángel evocaba inmediatamente la esfera celestial". Mientras que Agatas comentaba que "la imagen se imprime dentro del que la contempla" ${ }^{44}$. Naturalmente, no todo el mundo estaba tan sensibilizado como para que se puedan generalizar tales actitudes frente al arte visual ${ }^{45}$. Los Padres nos han revelado que su conocimiento de la mitología y su familiaridad con ella, no sólo no les era un estorbo para la comprensión de los misterios cristianos, sino que podía tomarse como vehículo de comunicación con el mundo pagano, que en gran parte estaba todavia por cristianizar. Para este uso, sin embargo, era necesario saber emplear el método alegórico que utilizaban ya los filosófos paganos, y leer más allá del contenido directo, material o mítico, elevando las imágenes a la categoría de símbolos. Sentido material y sentido espiritual convivian ya en el texto mismo de las Escrituras, como bien claro había ya enseñado San Pablo, un sistema exegético que en Filón de Alejandría se convierte en el único verdadero, y al que se acostumbraron la mayoría de los escritores cristianos. Es este mismo sistema que no podemos rechazar por las buenas al enfrentarnos hoy con el extenso material decorativo de las antiguos edificios de culto. Mosaicos con motivos que a simple vista pueden parecernos sin otro contenido que el puramente estético, realista o incluso práctico, podrian ser portadores de un simbolismo cristiano o judio relacionado con su origen iconográfico. Sólo con el auténtico conocimiento de éste, que a veces puede ser muy complejo, como es el caso del Zodíaco de las sinagogas, nos permitirá sentir una cierta tranquilidad por haber entendido debidamente el mensaje. En las otras partes que completan este trabajo hemos intentado recoger los varios aspectos de cada uno de los temas escogidos. Sin pretender ser exhaustivos, no sólo podremos percibir la compleji. dad del tema sino tal vez contemplar también ante nosotros un camino abierto que nos lleve a la auténtica comprensión del mensaje.

44 Antologia Palatina 1,33 y 34.

45 Estamos completamente de acuerdo con C. Dauphin, cuando al final de su análisis sobre el posible simbolismo de los "rollos habitados" de los sarmientos de la vid que tanto fue representado en los mosaicos, concluye distinguiendo tres modos de "lectura" de aquel motivo decorativo, según tres tipos de personas que podian contemplarlos: 1. La gente sencilla, y sobre todo los agricultores, podrian fácilmente identificarse con las personas que veian representadas ejecutando sus trabajos diarios para sacar de la tierra su sustento. 2. Otros, de más fino entendimiento, verían en las escenas una ilustración del deber del hombre de ofrecer los frutos de su trabajo a Dios, creador de todas las cosas. 3. Los más letrados de entre los fieles, y sobre todo los clérigos, conocedores de los textos bíblicos, podrían extraer enseñanzas simbólicas incluso de cada detalle de la composición (DaUPhiN, 1978: 31-34). 


\section{BIBLIOGRAFIA}

Afoldi-Rosenbaum, E. (1975): "A Nilotic Scena on Justinianic Floor Mosaics in Cyrenaican Churches", La mosaique gréco-romaine II, Paris, págs. 149-153, PI. LV-LVIII (Bet Leontis pl.LVIII,2).

Alfoldi-Rosenbaum, E. \& Ward-Perkins, J. (1980): Justinianic Mosaic Pavements in Cyrenaican Churches, Rome, págs. 32-62.

Avi-YonAH, M. (1981): Art in Ancient Palestine (trabajos reeditados por Hanna Katzenstein y Yoram Tsafrir), Jerusalem.

BALTY, J. (1977): Mosaïques de Syrie, Bruxelles.

BALTY, J. (1988): "lconographie et réaction païenne», en Mélanges $P$. Levêque. 1. Religion, Paris, págs. 17-32.

Balty, J. (1995): Mosaiques antiques du Proche Orient, Paris.

BIEBEL, F.M. (1938): "Mosaics", en C.H. Kraeling (ed.), 1938, Gerasa - City of the Decapolis, New Haven, págs. 297-351.

BLAZQUEZ, J.M. (1990): "Temas de mitología pagana en iglesias cristianas del oriente", Antigüedad y Cristianismo 7: 367-384.

Buschmausen, H. (ed.) (1986a): Byzantinische Mosaiken aus Jordanien, Wien.

Buschiausen, H. (1986b): "Die Marienkirche von Madaba und der Saal des Hippolytos", en Buschhausen 1986a, págs. 139-156.

CRowFOOT, J.W. (1941): Early Churches in Palestine, London.

DAUPHIN, C. (1978): "Symbolic or Decorative? The Inhabited Scroll as a Means of Studying Some Early Byzantine Mentalities", Byzantion 48:10-34.

Dunbabin, K.M.D. (1978): The Mosaics of Roman North Africa. Studies in Iconography and Patronage, Oxford.

Figueras, P. (1980): "Beersheva in the Roman-Byzantine Period", Boletín de la Asociaciación Española de Orientalistas 16: 135-162.

Figueras, P. (1992): "Découvertes dans le Néguev", Le Monde de la Bible 78:60-63.

Figueras, P. (1996): "Las pinturas murales de la sinagoga de Dura Europos a la luz de la polémica judeo-cristiana", Boletín de la Ascociación Española de Orientalistas 32:207-219.

GAZIT D. and LENDER, I. (1992): "St. Stephan's Church at Beer-Shema', Northern Negev", Qadmoniot 25 (97-98): 33-40 (en hebreo).

Goodenough, E.R. (1953-1968): Jewish Symbols in the Greco-Roman Period, 13 vols. (Bollingen Series XXXVII).

HACHLILI, R. (1988): Ancient Jewish Art and Archaeology in the Land of Israel, Leiden.

HALdON, J.F. (1990): Byzantine in the Seventh Century: the Transformation of a Culture, Cambridge.

LEHMANN, K. (1945): «The Dome of Heaven", Art Bulletin 27: 1-27.

LEVINE L.I. (ed.) (1981): Ancient Synagogues Revealed, Jerusalem.

LIMC = Lexicon Iconographicum Mythologiae Classicae, Zürich-München, 1992.

Lopez Monteagudo, G. (1995): "El nacimiento del arte cristiano», en J. Alvar et al., eds, 1995. Cristianismo primitivo y religiones mistéricas, Madrid, págs. 405-434.

LoPez MONTEAGudo, G. (1997): "Personificaciones alegóricas en mosaicos del Oriente y de Hispania: la representación de conceptos abstractos", en La tradición en la Antigüedad Tardia, Antigüedad y Cristianismo 14: 335-361.

Maguire, H. (1987): Earth and Ocan-The Terrestrial World in Early Byzantine Art, London.

OrEN, E. (1982): “Les cités hellénistiques et romaines", Le Monde de la Bible 24:24-27.

OVADIAH, R. and A. (1987): Hellenistic, Roman and Early Byzantine Mosaic Pavements in Israel, Rome.

Piccirillo, M. (1986a): "Katalog», en Buschhausen 1986a: 211-251.

Piccirillo, M. (1986b): "La cité de Nébo", Le Monde de la Bible 44: 30-39.

Piccirillo, M. (1987): "Le iscrizioni di Um er-Rasas - Kastron Mefaa in Giordania, I (19861987)", Liber Annuus, Studium Biblicum Franciscanum 37: 177-239.

PICCIRILlo, M. (1993): The Mosaics of Jordan, Amman.

Potin, J. (1993): "La vie quotidienne au monastère Sainte-Catherine", Le Monde de la Bible, 82: $36-40$.

Rahmani, L.Y. (1975): "The Erez Mosaic Pavement", Israel Exploration Journal 25: 21-24, pls. 3-4. 
Rammani, L.Y. (1996): "Representations of the Seasons on a Christian Lead Coffin from Nirim", 'Atiqot 28: 147-159, figs. 1-12.

RAHNER, H. (1963): Greek Myths and Christian Mysteries, New York.

Rosenthal, R.: "Late Roman and Byzantine Bone Carvings from Palestine", Israel Exploration Journal 26 (1976) 96-103, pls. 22-23.

Roussin, L. (1981): "The Beit Leontis Mosaic: An Eschatological Interpretation", Journal of Jewish Art 8: 6-19.

SEVCENKo, I. (1980): "A Shadow of Virtue: The Classical Heritage of Greek Christian Literature (Second to Seventh Century)", en K. Weitzmann, ed., 1980, Age of Spirituality, (Metropolitan Museum of New York), Princeton, págs. 53-73.

TALGAM, R. (1998): "Mosaics in Israel in the Light of Recent Discoveris", Qadmoniot 31 (116): 74-89 (en hebreo).

WEISS Z. and NETZER, E. (1994): Zippori, Jerusalem (en hebreo).

WEISS Z. and NETZER, E. (1997): "The Hebrew University Excavations of Sepphoris", Qadmoniot 30 (113): 2-21 (en hebreo).

WeITZMANN, K. (1951): Greek Mythology in Byzantine Art, Princeton.

ZAYADINE, F. (1986): "Peintures murales et mosaïques à sujets mythologiques en Jordanie", en L. Kahil, C. Augé, P. Linant de Bellefonds, eds., 1986, Iconographie classique et identités régionales, Paris 26 et 27 mai 1983, Athens-Paris, págs. 407-432. 


\title{
Motivos paganos en mosaicos cristianos y judíos de Oriente: problemática e interpretación (II) ${ }^{1}$
}

\author{
PAU Figueras ${ }^{2}$
}

\begin{abstract}
RESUMEN
A continuación del artículo introductorio (arriba, pp. 259-294), el presente trabajo examina en detalle las figuras mitológicas relacionadas con dos temas frecuentes en los mosaicos de iglesias bizantinas, esto es, el agua y la tierra. El primero incluye tanto las representaciones de paisajes y escenas nilóticas, como las del mar en forma de

la figura de los dioses que 10 representan (Thalassa-Tetis, Abyssos y

Océano). El segundo motivo está representado no sólo por los trabajos agricolas y por los frutos que la tiera proporciona, sino por la propia figura de la diosa Gea (la tierra) y de los Karpoio genios de los frutos. Textos biblicos y patristicos relativos conducen a

interpretar todos estos motivos como símbolos de la vida, tanto terrestre como eterna, que proviene sólo de Dios.
\end{abstract}

ABSTRACT

Following the introductory chapter (above, pp. 259-294), the present study analyzes in detail the mythological fgures related to two frequent motifs found in the mosaics of the Byzantine churches, namely ater and earth. The first motiv includes representations of Nilotic landscapes and scenes, as well as the sea gods (Thalassa-Tetys, Abyssos and Okeanos). The second motif is not only represented by the agricultural labors and the fruits of the earth but also by the figures of the earth goddess Ge hersel and of the Karpoi or genii of the fruits. Biblical and Patristic texts lead us to interpret all these motifs as symbols of both the eartly and the elernal life that are only Godgiven.

Este artículo es continuación del trabajo anterior.

Departamento de Biblia y Próximo Oriente Antiguo de la Universidad Ben-Gurion del Negev (Beer-Sheva, Israel). 


\section{EL AGUA Y SUS HABITANTES}

\section{El Nilo y escenas nilóticas}

Este es uno de los motivos que podriamos llamar paisajísticos de más difusión en nuestros mosaicos. Aparece innumerables veces en las villas de Antioquía y su región ${ }^{3}$ tanto antes como después de la era constantiniana, y su contexto es allí profano, decorando los pavimentos de villas rústicas y mansiones señoriales ${ }^{4}$. Con una gran variedad de colores y matices, el mismo tema de las aguas rellenas de peces, con atributos del Nilo o no, lo encontramos en dos mansiones señoriales romanas descubiertas en Israel, la primera en la ciudad de Scitópolis o Bet Sheán (Bet Leontis) (Avi-Yonah 1981: Pl. 43), otra en la ciudad de Séforis (NetzerWeiss 1992, 1993, 1995), y otras dos decorando pavimentos de dos villas rústicas: una en las cercanías de Jerusalén ('Ein Ya'el), y otra cerca de la ciudad de Lydda (Lod). Estos dos últimos, los más antiguos de su tipo en Israel, son de una gran riqueza de color y una gran finura de estilo.

Pero ya antes de estos últimos descubrimientos, eran bien conocidos los dos cuadros de mosaico nilótico del transepto de la iglesia bizantina de la Multiplicación de los Panes y los Peces de Tabga, junto al Lago de Tiberíades. Aunque $\sin$ las figuras humanas que dan mucho interés al gran mosaico de Séforis, el de Tabga llama la atención por la elegancia de sus sus flores y de sus aves acuáticas, y por su agradable composición, que poco tiene del típico mosaico bizantino (Avi-Yonah 1972a: 135, fig.; id. 1981: Pl. 52).

El mosaico de Tabga (fig. 1) está fechado en el siglo $v$, y es probablemente el más antiguo entre los mosaicos nilóticos que decoran tantas iglesias en Israel y en Jordania. Estas iglesias son: en Jordania las de San Juan Bautista (Kitzinger 1965: fig. 18) y de los Santos Pedro y Pablo de Gerasa, la capilla del mártir Teodoro de Mádaba (Piccirillo 1993: 117, figs. $109,111,12-15)^{5}$, la iglesia del sacerdote Wail de Umm er-Rasas-Kastron Mefa'a (ibid.: 141-143, fig. 398) ${ }^{6}$, los pavimentos de Umm al Manabi (ibid.:

E.g. LEVI 1947, II, PI. LXXXIV, b, mosaico en el terreno de Rassim Bey Adali.

El mejor estudio monográfico del tema es el de J. BALTY, 1984, “Thèmes nilotiques dans la mosaique tardive du Proche-Orient", in Alessandria e il mondo ellenistico. Studi in onore di Achille Adriani, III, pp. 827-834. Muchas de las escenas nilóticas fueron también representadas por LAVIN (1963).

En esta capilla están representados los cuatro ríos del Paraiso: Gihón, Tigris, Fisón y Eufrates, en los octágonos de los cuatro ángulos de la alfombra musiva.

Piccirillo llama también escena nilótica a la cenefa de ciudades alrededor del motivo central en la iglesia de San Esteban del mismo lugar ('BID. 238-239, figs. 358, 380, 383, 385). Nosotros más bien la llamariamos escena marítima, pues ciudades como Casium no estaban situadas junto a) Nilo sino junto al Mediterráneo. 

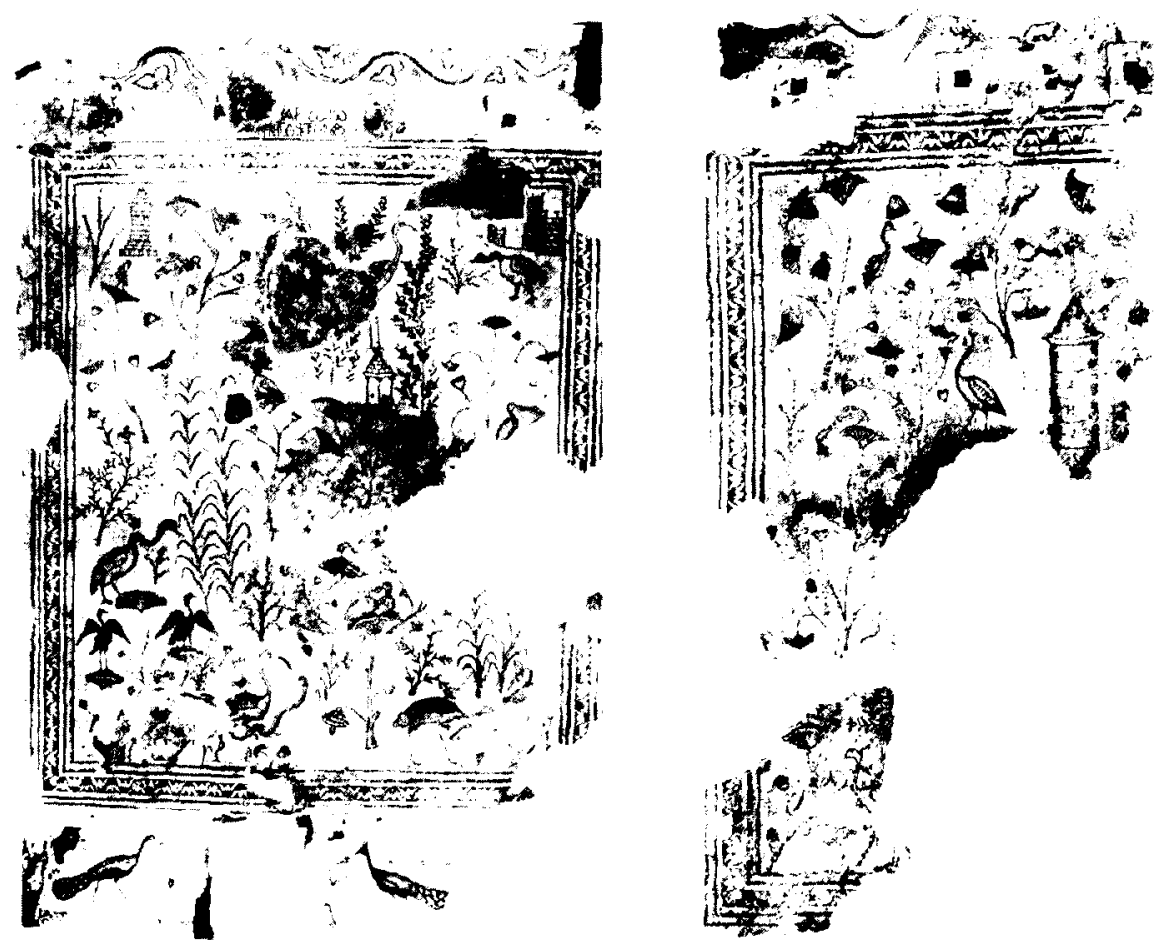

Fig. 1. Mosaico nilótico, iglesia de Tabga (Avi-Yonah 1981, pl. 52).

341, fig. 752) y Zay al-Gharby (ibid.: 37, 318, fig. 660); y en Israel la iglesia de El-Haditha (Avi-Yonah 1972b; Hachlili 1997, PI. 14, B.). Además, tenemos noticia de que también en la capilla del bautisterio de la iglesia norte de Sobota (Shivta), en el desierto del Néguev, había una representación de los cuatro ríos del Paraíso, uno de los cuales, como es sabido, era Gihón, que se identificaba con el Nilo?

Los elementos básicos que integran todos estos mosaicos pueden reducirse a dos principales: el agua y los peces. Pero en muchos de ellos tenemos también flores y aves acuáticas, mientras que en algunos vemos también barcas, con pescadores y sin ellos (El-Haditha) (fig. 2), cocodrilos, nilómetros (Tabga, Séforis, Bet Leontis) (fig. 3). En algunos casos está

Fue nuestro llorado maestro, el P. Bellarmino Bagatti, quien nos comunicó haber tenido noticia de este mosaico por vía de sus propios descubridores, de la expedición Colt, que excavaron dicha iglesia en el año 1934. 


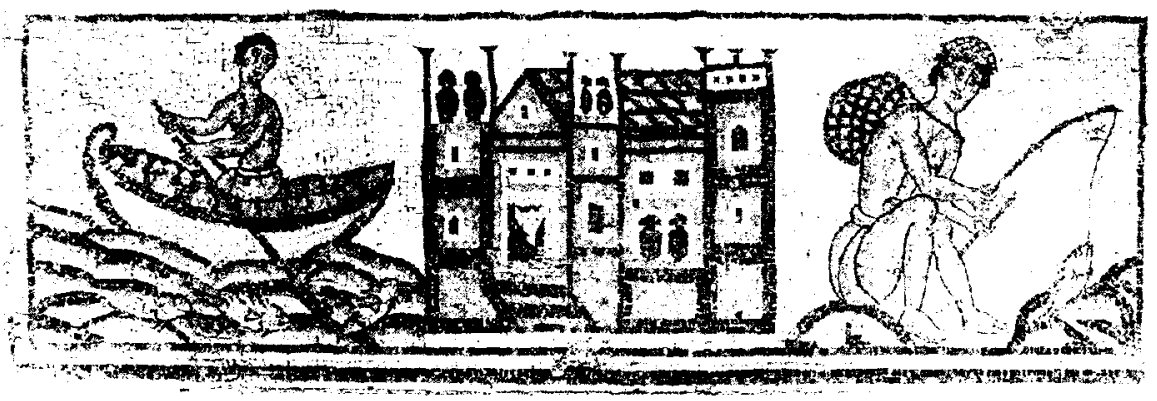

Fig. 2. Pescadores. Iglesia de El Mukhayyat (Piccirillo 1986b, pág. 35, fig. 46).

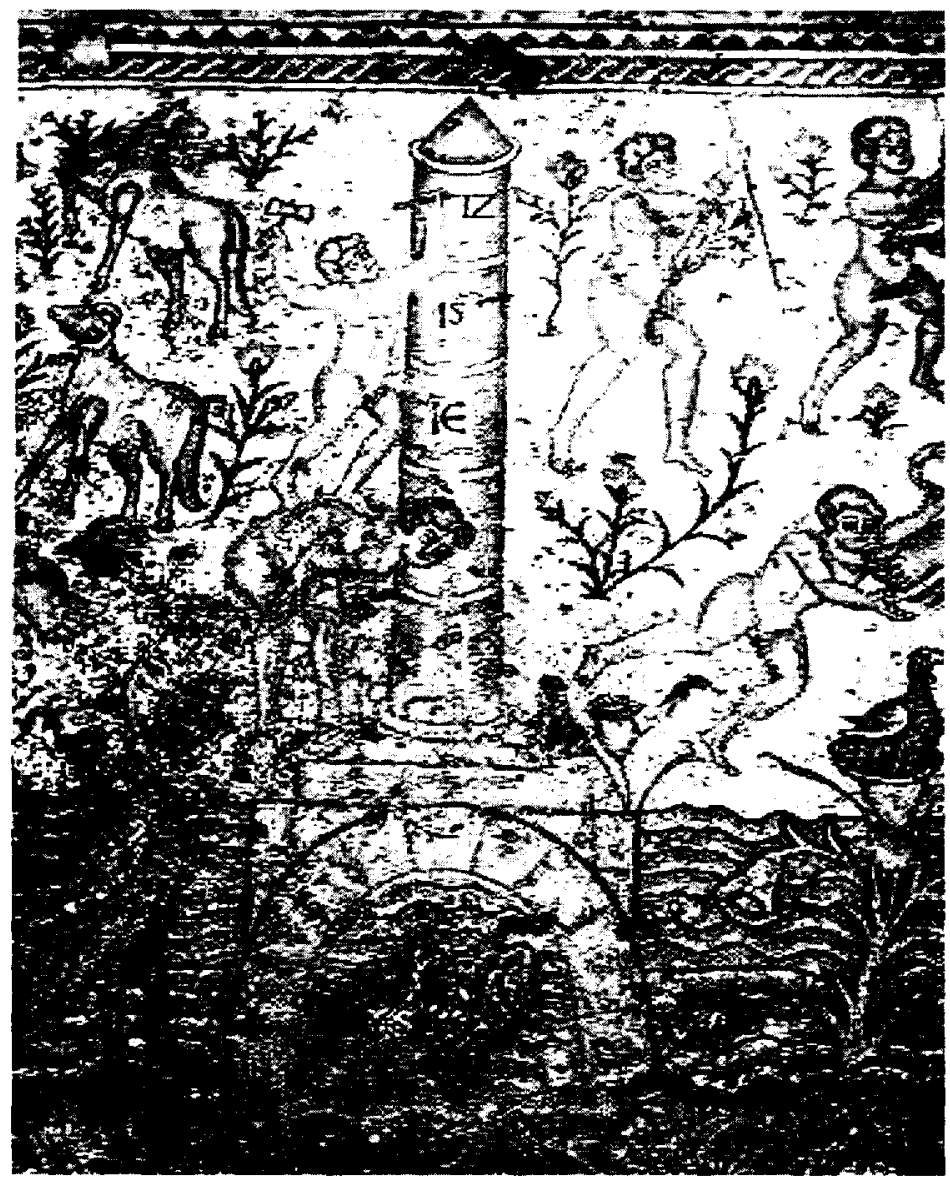

Fig. 3. Nilómetro. Casa del Festival del Nilo, Séforis (Weiss-Netzer 1994, pág. 47). 


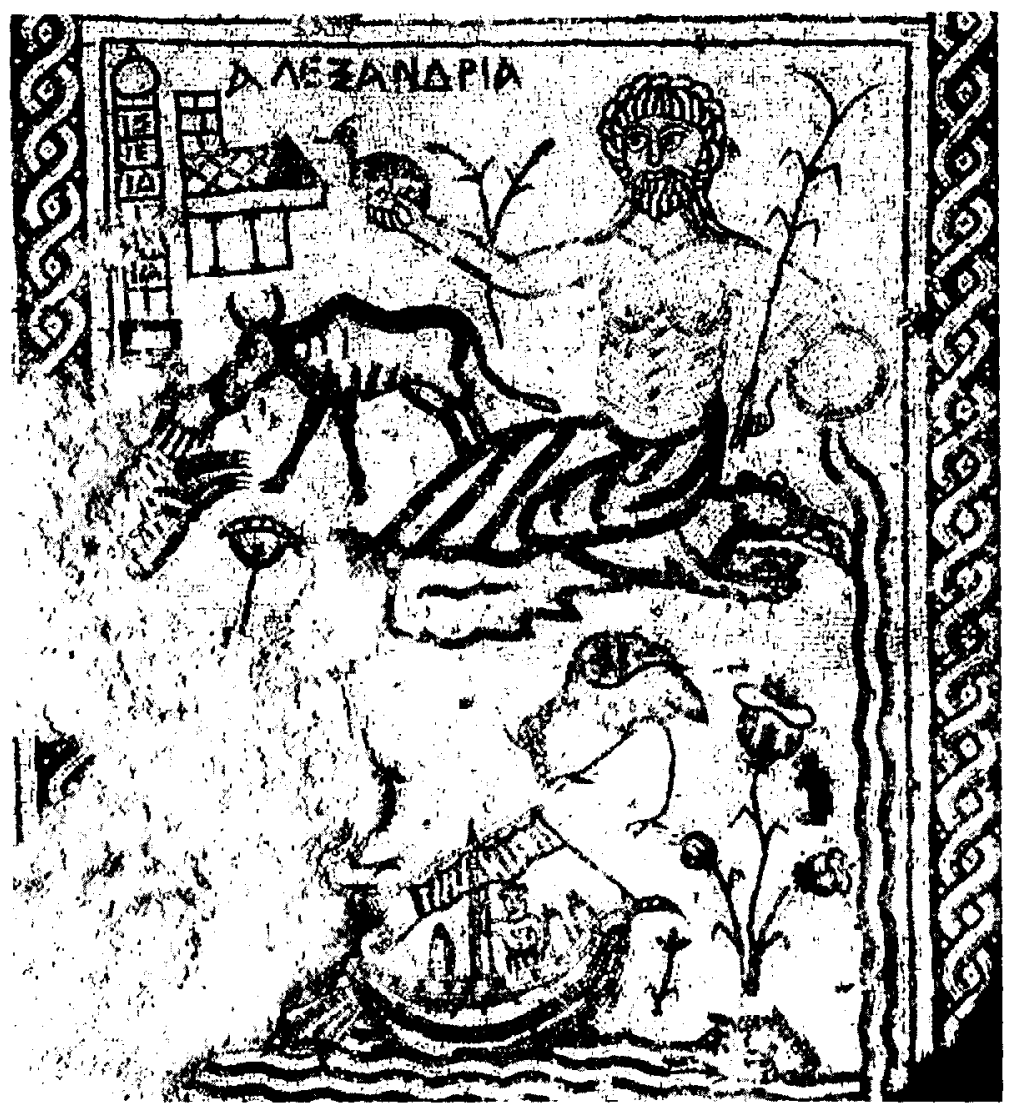

Fig. 4. Personificación del Nilo. Bet Leontis, Bet Sheán (Avi-Yonah 1981, pl. 43, 1).

también la representación esquemática de la ciudad de Alejandría, con la inscripción que la identifica (Bet Leontis, Séforis). En un caso, la inscripción que acompaña la ciudad dice EГYПTOL (Haditha). Hay casos en que el Nilo está personificado por un hombre de mediana edad recostado y apoyándose en una jarra de donde brota el agua del río (Bet Leontis) (fig. 4). Y en el gran mosaico de Séforis, al que hoy se llama comúnmente en Israel "mosaico de la fiesta del Nilo", vemos a dos personajes recostados, uno mal conservado a la derecha, que sería casi seguro el Nilo, y otro a la izquierda, una mujer de pecho desnudo y sosteniendo un gran cuernno de la abundancia, que es identificada como el propio Egipto por una inscripción: AIГY[ПTOE]. En este mosaico se reproducen además un sinnúmero de escenas de animales, algunos pacíficos, otros en lucha entre sí, 


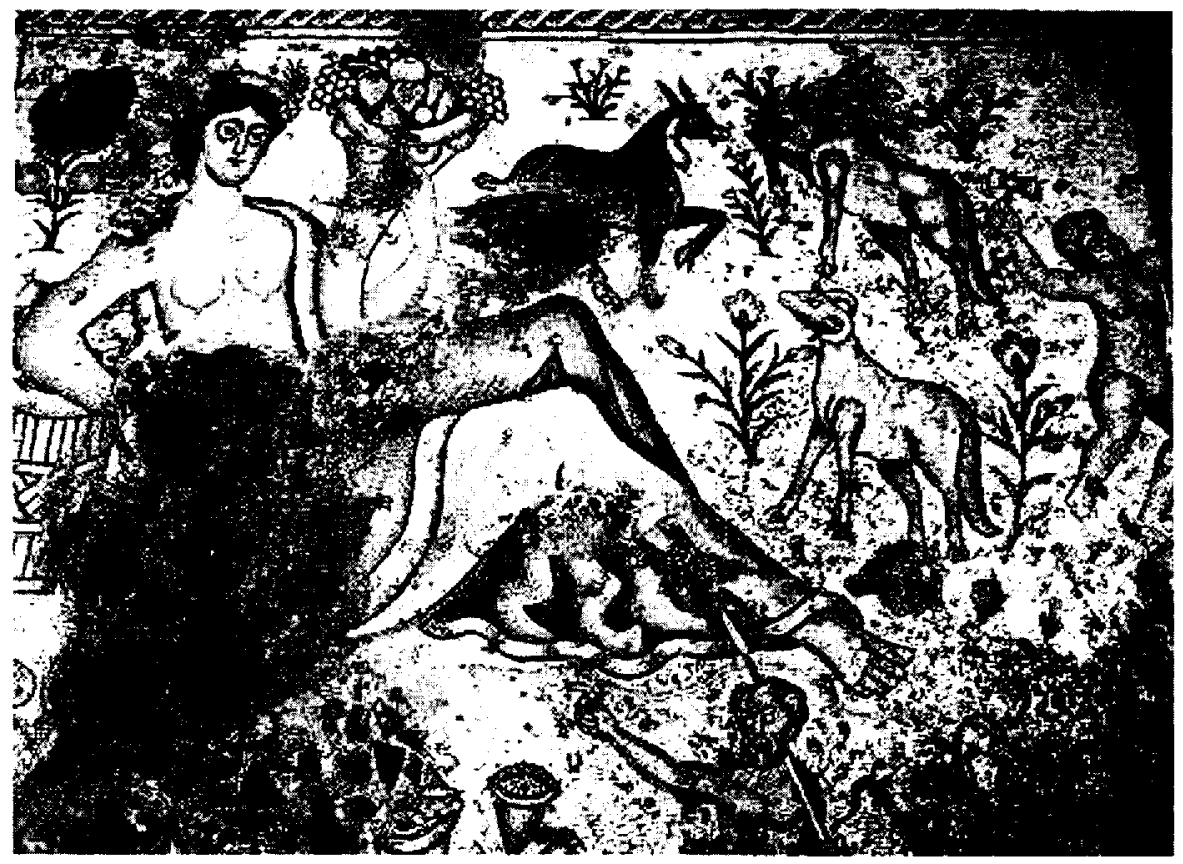

Fig. 5. Personificación de Egipto. Casa del Festival del Nilo, Séforis (Weiss Netzer 1994, pág. 47).

como también plantas de todo género, y una altísima columna sosteniendo estatua, que bien podría representar la que se levanta todavía hoy en Alejandría, llamada de Pompeyo (fig. 5).

En cuanto a la interpretación que se debe dar a este tema nilótico en las iglesias, el hecho de que se encuentre también, y ciertamente en su origen y difusión, en contextos que nada tienen que ver con el culto cristiano o judio ${ }^{8}$, impide a la mayoría de los estudiosos ver en él una alegoría de carácter religioso. Sin embargo, no estamos del todo privados de ayuda textual para darnos cuenta de que el gusto cristiano por las escenas de ríos, y del Nilo como río por excelencia, tenía una doble connotación bí-

8 "We all know, of course, of the wide-spread use of Nilotic motifs in painting and in mosaic art troughout the Roman period. They also appear as control marks on a number of Republican coins struck in the period of the Civil Wars, where they must be interpreted as symbols of the Isis cult. Considering that as early as the first half of the first century B.C. elements from the Nile-scape were isolated and used as individual symbols, it does not seem surprising that these motifs should have found their way into the pattern books of mosaic workshops. And their connection with a popular pagan cult may be in part responsible for their survival in Christian contexts" (ALFOLDI-ROSENBAUM 1975: 152). 
blica. El Nilo era uno de los cuatro ríos que regaban el Paraíso terrenal, pues era identificado tradicionalmente con el río Gihón por este versículo biblico: «¿Qué tienes que ver tú con la tierra de Egipto, para que bebas del agua del Gihón?" Este texto de Jeremías 11:18 es citado por Procopio de Gaza con esta intención de identificación ${ }^{9}$. $Y$ en su tratado de topografía cristiana, Cosmas Indicopleustés en el s. VII lo dejó bien claro: “El Gihón, que nace en las regiones de Etiopía, atraviesa toda Etiopía y todo Egipto, y va a desmbocar por muchas cabezas en nuestro golfo" ${ }^{10}$. En la mentalidad de la época, bastaria esta sola connotación con el Paraíso terrenal para que la representación del Nilo, su paisaje, su flora y su fauna, despertasen en las mentes de los fieles la idea de la vida, y vida en abundancia en la creación renovada de un Paraiso celestial. El significado de las escenas vendría así a juntarse al de la mayor parte de los demás mosaicos con temas de naturaleza, animales, árbol de vida, y sobre todo la vid repleta de fruto, plantada como está en un cántaro lleno de agua.

Pero hay más, puesto que otras representaciones del mismo tema, aunque no en mosaicos de Siria o Palestina, llevan inscripciones pertinentes, por las cuales es fácil ver que los autores de tales escenas nilóticas, o quien las hubiera encargado, lo habian hecho con una intención particular. Por ellas se ve claro que lo que les interesaba era el tema del agua como elemento que mostraba el poder divino, y era en frases bíblicas donde encontraban aquella relación. Una de las representaciones está en un mosaico de Qasr el-Lebia, en el Norte de África, en una capilla nordoriental del edificio, que fue publicado y estudiado por Alfödi-Rosenbaum. Es de lamentar que la autora del estudio parece no darse cuenta de que la primera parte de la inscripción que acompaña la escena, dentro de un medallón, es una cita del Salmo 92:5, último versículo de un corto salmo que canta la majestad de Dios, comparándola al ruido de ríos desencadenados:

"Levantan los rios, Señor,

levantan los rios su voz,

levantan los rios su fragor,

y con su fragor te claman.

Pero más que el rumor de muchas aguas,

más poderoso que el oleaje del mar,

es poderoso el Señor en lo alto " (Salmo 92:3-4)

Estas palabras no son las de la inscripción, pero sí su contexto inmediato, y es indudable que la cita no fue tomada casualmente de ese Salmo,

PRocopIo de GAZA, Comment. In Isaiam, PG 87, 2152.

Cosmas Indicopleustés, Topographia Christiana, Lib. II, PG 88, 117. 
que justamente termina, en la versión griega de los $L X X$, con un grito de esperanza por un final eterno y maravilloso: "hasta el más grande de los días». El medio versiculo citado en la inscripción dice así: «Tus testimonios (marturia) son verídicos, Señor, tu santidad está sobre tu casa».

La segunda inscripción mencionada por Alföldi-Rosenbaum (ibid.) proviene de una cisterna de Salamis, en Chipre, fechada en el siglo VI y decorada con un fresco del mismo tema que nuestros mosaicos, pero ostentando también una efigie central de Cristo. Más que en ninguna otra reproducción del tema cuadra aquí la inscripción bíblica: «La voz del Señor está sobre las aguas", tomada del Salmo 27:3.

Es indudable, pues, que existía una intención detrás de la representación de unas escenas del agua, que de por sí solas nos costaria relacionar con algo religioso, y más con un lugar de culto ${ }^{11}$. Aquella intención era, naturalmente, la de comunicar la esperanza de una felicidad eterna en una vida futura, basada en el poder maravilloso de Dios. La primera de las inscripciones referidas no menciona las aguas pero sí la santidad de la casa de Dios, tomada del contexto del mismo Salmo. De modo que es realmente el recuadro bíblico lo que nos permite comprender el por qué de las escenas nilóticas en una iglesia. Su texto nos hace ver la correlación existente entre la escena representada y el lugar de culto que adorna. La santidad que llena la casa de Dios es resultado de su gran poder, que se manifiesta en las aguas del Nilo. La abundancia de vida que esas traen a los hombres son símbolo de la vida feliz y perenne en un Paraíso celestial. Un concepto se ilustra y complementa por el otro.

En resumen, tenemos un caso típico de la correlación entre un tema de origen pagano, como sería el del mosaico acuático de 'Ein Ya'el (fig. 6), pero que se continúa usando en la tradición cristiana, despojado ya de su origen mitológico e incluso de cualquier valor alegórico. La iglesia lo em-

\footnotetext{
Habría que hacer aquí mención de los bautisterios y de su decoración. Son bien conocidos los dos bautisterios de Ravenna, de época justiniana, que ostentan, en el centro de las grandes bóvedas, la representación del Bautismo de Cristo en el rio Jordán. Este último aparece, en cada uno de los dos mosaicos, personificado bajo los atributos del dios del mar, Oceanus, aunque identificado por la inscripción en latín, IORDANIS. Por desgracia, no hay en oriente nada semejante. No se ha conservado ni una sola bóveda de edificio cristiano, aunque sabemos que las habia, tanto por las descripciones de Coricio de Gaza como por los restos conservados de edificios martiriales de forma redonda (Sto. Sepulcro de Jerusalén) u octogonal (Monte Garizim, Cesarea, Cafarnaúm, etc.). Por otra parte, los mosaicos que decoraban algunos de los bautisterios, como los del Monte Nebo (PICCIRILLO 1993), no tienen relación alguna con el tema del agua. Claro está que a veces la propia inscripción que acompaña la decoración no se refiere a aquel lugar ni siquiera con el nombre de "bautisterio", que incluiria el concepto de agua, sino de "fotisterio", refiriéndose al tema de la iluminación espiritual (así, por ejemplo, en la iglesia de Kursi, probable Guerguesa de los bizantinos, en la orilla oriental del Lago de Tiberíades).
} 


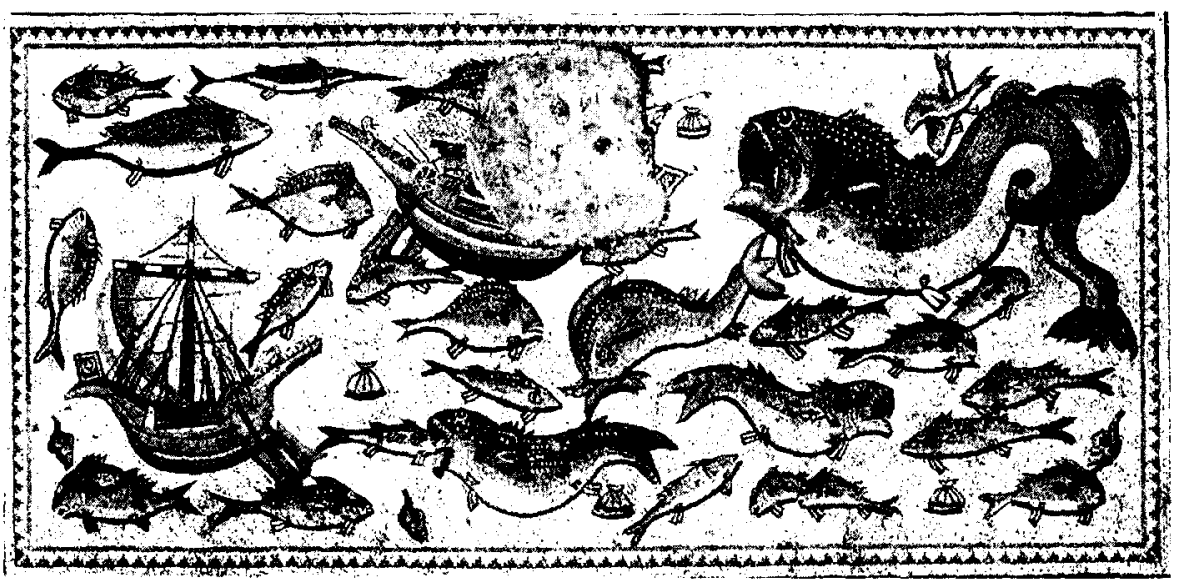

Fig. 6. Mosaico de los peces. Villa romana, Lod (Talgam 1998, cubierta).

plea, y con profusión, para decorar sus lugares de culto, encontrando en él un agradable medio de comunicar la esperanza en la salvación eterna en el Paraíso celestial. No creemos en absoluto que se deba buscar un simbolismo de detalle en las figuras y escenas del mosaico, pues eso iria en contra de la intención general de sus autores. Los textos aducidos, tanto de los escritores antiguos como de las escasas inscripciones que acompañan este tipo de mosaico, constituyen la única garantia, pero una garantía real, de que estamos en el buen sendero para descubrir la motivación y las ideas clave de la interpretación.

Tampoco pretendemos que las representaciones nilóticas de la época bizantina que no se encuentran en ambientes de culto sino en casas privadas, edificios públicos o semipúblicos, como podría ser el caso de Séforis, la escena nilótica tenga que ser portadora de un simbolismo religioso. En Bet Leontis, sin embargo, el hecho de que el tema nilótico se encuentre junto a la representación del mito de Ulises amarrado al mástil (véase págs. 265-267, fig. 3), podría dar lugar a duda. Por lo demás, cabe mencionar que en este mismo mosaico se encuentra un elemento, no mencionado hasta ahora, que podría acrecentar la carga simbólica del mosaico. Se trata del grupo formado por un cocodrilo atacando una vaca, y junto a ellos un mozo que quiere defender a ésta. Este grupo aparece también en la escena nilótica grabada en una viga del techo de la iglesia justianianea del Sinaí. El hecho de que dicho grupo aparezca en una escena nilótica en ambiente religioso es suficiente para que AlföldiRosenbaum la tenga como probablemente simbólica: «En un contexto cris- 


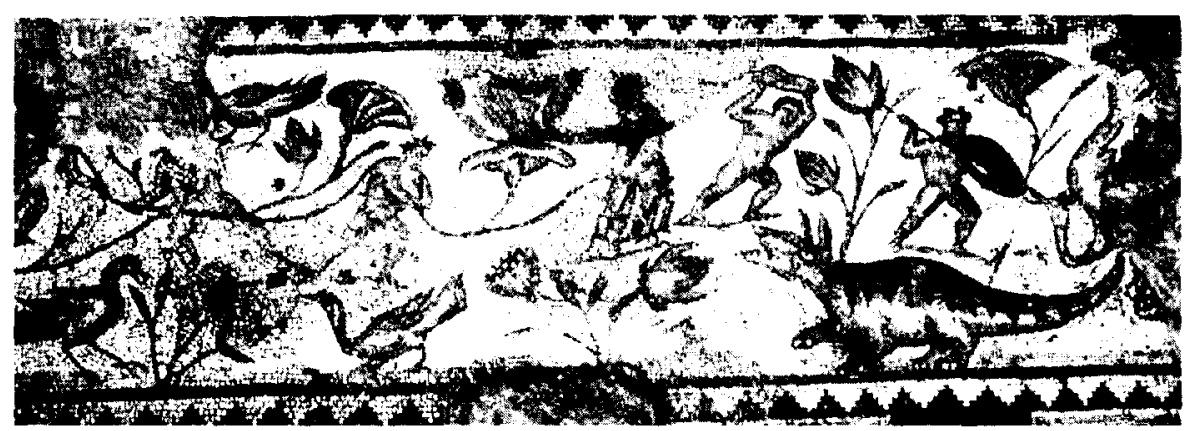

Fig. 7. Escena nilótica. Mosaico de Dionisos, casa romana, Séforis (Talgam-Weiss 1988, pág. 98).

tiano, escribe ella, el cocodrilo podría significar el poder de Satanás..." (Alföldi-Rosenbaum, ibid.). Sin embargo, también existe en Israel, y concretamente en el triclinio dionisíaco de Séforis un pequeño mosaico nilótico que vino a sustituir en cierto momento una representación anterior (fig. 7). $Y$ en esta escena nilótica aparecen unos jóvenes desnudos, uno lanzando una gran piedra contra un cocodrilo, el otro atacando con su lanza a lo que parece ser un avestruz (Weiss-Talgam 1980: 234). No podemos aquí hablar de simbolismo religioso alguno, tanto por el contexto iconográfico, que no pertenece al mismo tema sino al dionisíaco, como por la falta de inscripción que nos facilite la interpretación, si quisiéramos buscar una.

Finalmente, habría que señalar aún, con $\mathrm{E}$. Kitzinger, una de las máximas autoridades en la materia, que las precisiones geográficas (inscripciones de "Alejandría", "Egipto", etc) no disminuyen la carga de valor simbólico que debe atribuirse a las escenas nilóticas en las iglesias ${ }^{12}$.

\section{El mar y sus dioses}

Aunque no tan frecuente como el tema nilótico, el del mar y sus dioses ha ejercido también su poderosa atracción entre los artistas clásicos, que lo representaron innumerables veces en los mosaicos. De tiempos anteriores a la cristinianización masiva de Siria, lo encontramos varias veces en las villas de Antioquía y alrededores. Véanse por ejemplo los reprodu-

\footnotetext{
Sus palabras son de comentario positivo sobre la exposición de Alföldi-Rosenbaum (IBIE. p. 153): «...même au Vle s., la précision de l'allusion géographique n'empêche pas que l'on ait songé à évoquer un paysage idillique ou encore l'idée de lutte du bien contre le malı.
} 
cidos por D. Levi: Mosaic of Thetis and Oceanos, House of the Calendar (Levi 1947, I: 38-39; II, PI. VI); Pool of Thetis, bajo el Bath F (Levi 1947, II: PI. LXII; PI. CLXIII, a); bustos de Océano y Tetis en House of the Boat of Psyches (ibid. II: PI. CLVII, a-b); y los de House of the Sea-Goddess. Nada más natural que una decoración de ese género en el mundo romano que tanto apreciaba los beneficios del agua y los estableciemientos termales. La más espectacular de las representaciones del mar es sin duda, por su singular belleza y originalidad la figura de la diosa Tetis en un mosaico de Shabha (Philippopolis) en Syria, en la que el busto de la diosa está representado dentro de marco cuadrado, rodeado por alados erotes, algunos de ellos dentro de barcas. Sus cabellos son animales marítimos. Su mirada, de gran fuerza (Balty 1986, fig. 5). No falta hoy en Israel un magnífico ejemplo de villa rustica con mosaicos de tema marino. Es el que fue descubierto al sureste de Jerusalén, en el lugar llamado 'Ein Ya'el, nombre que ya indica la presencia de un manantial, y en efecto el agua mana todavia hoy de dentro de una cueva natural. El manantial fue aprovechado en el siglo III d.C. para la construcción de una magnífica villa que funcionó hasta bien entrada la época árabe. No es pues de extrañar que los temas iconográficos con que los dueños paganos de la villa quisieron decorar el pavimento de mosaico del triclinio fueran todos temas marinos. Además de escenas de nereidas cavalgando sobre ictiocentauros y de otros seres marinos, sobresale la vivaz cabeza de Tetis, rodeada por infinidad de peces (fig. 8) (Rapuano 1989: 14, fig. 2; Edelstein 1993:117, foto).

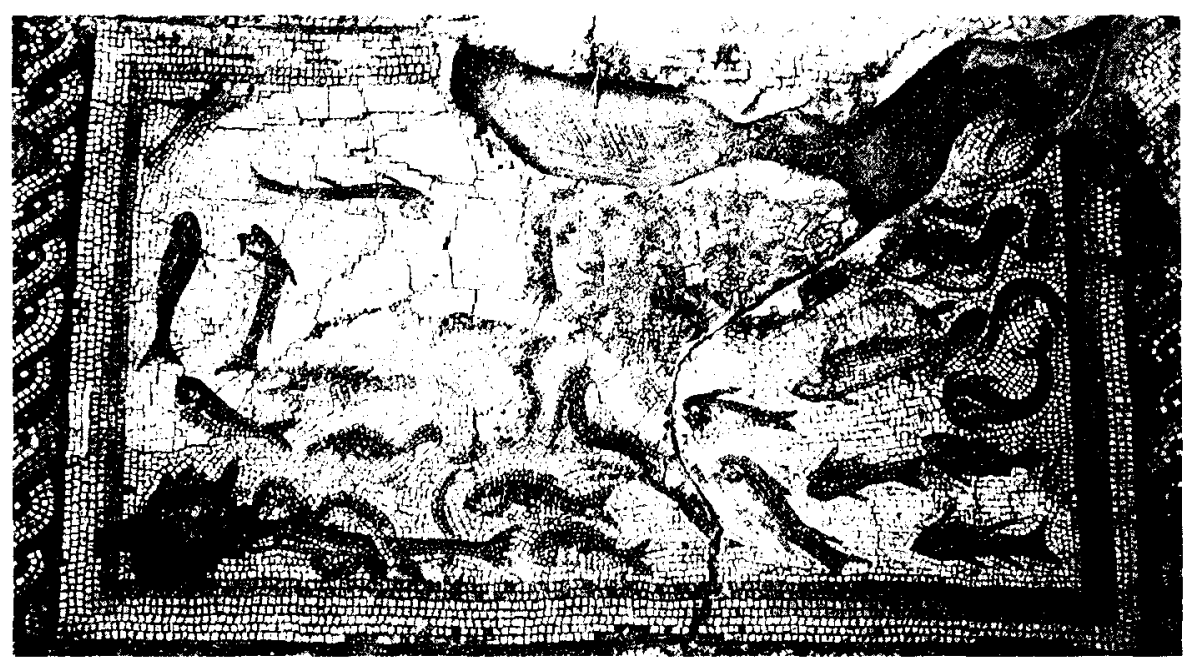

Fig. 8. Cabeza de Tetis, diosa del mar, entre peces. Villa romana de 'Ein Ya'el, Jerusalén (Edelstein 1993, pág. 117). 


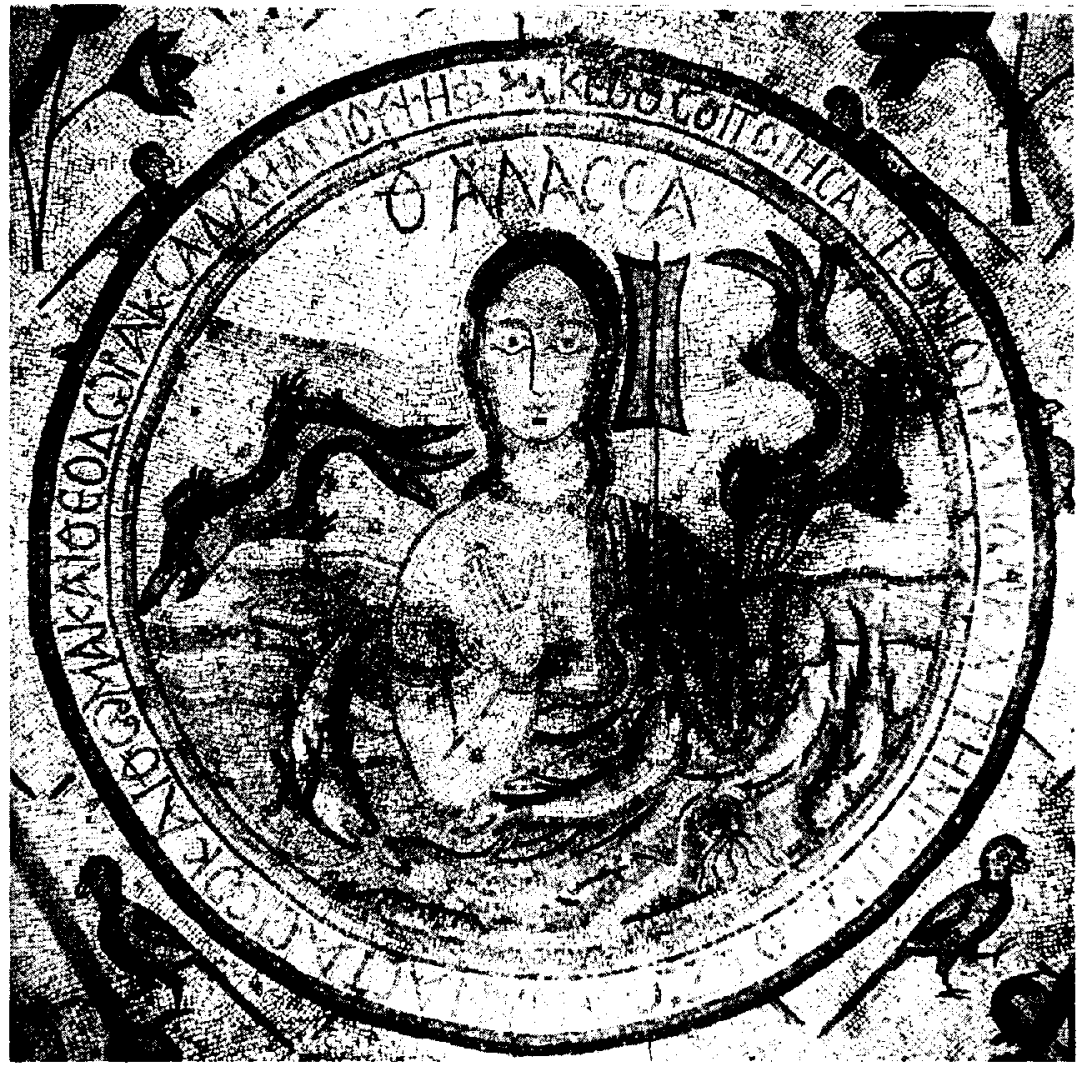

Fig. 9. Personificación del mar, Thálasa. Iglesia de los Apóstoles, Mádaba (M. Piccirillo 1986a, pl. XI).

A decir verdad, no sabemos qué valor, fuera del estético, atribuían los romanos a la presencia de las figuras mitológicas del mar, sobre todo la diosa Tetis y el dios Océano, personificaciones de los elementos naturales. Lo cierto es que luego, ya en tiempos cristianos y en ambientes de culto, no sólo persiste el tema del agua y del mar, sino también la presencia inveterada de aquellas mismas personificaciones: el busto de Tetis, aunque la inscripción la llama sólo $\theta \mathrm{A} \Lambda \mathrm{A} \Sigma \Sigma \mathrm{A}$, el mar, preside el mosaico de la nave central de la iglesia de los Apóstoles en Madaba (fig. 9) (Piccirillo 1993: 38, fig. 78) ${ }^{13}$.

13 Representada también en LIMC VIII, Thalassa 11. Tenemos allí también el paralelo de un mosaico de procedencia desconocida, con la misma representación, aunque muy diferente, y la misma inscripción | $\Theta A \Lambda \mid A \Sigma \Sigma A$, en $L I M C V I I \mid$, Thalassa 14. 


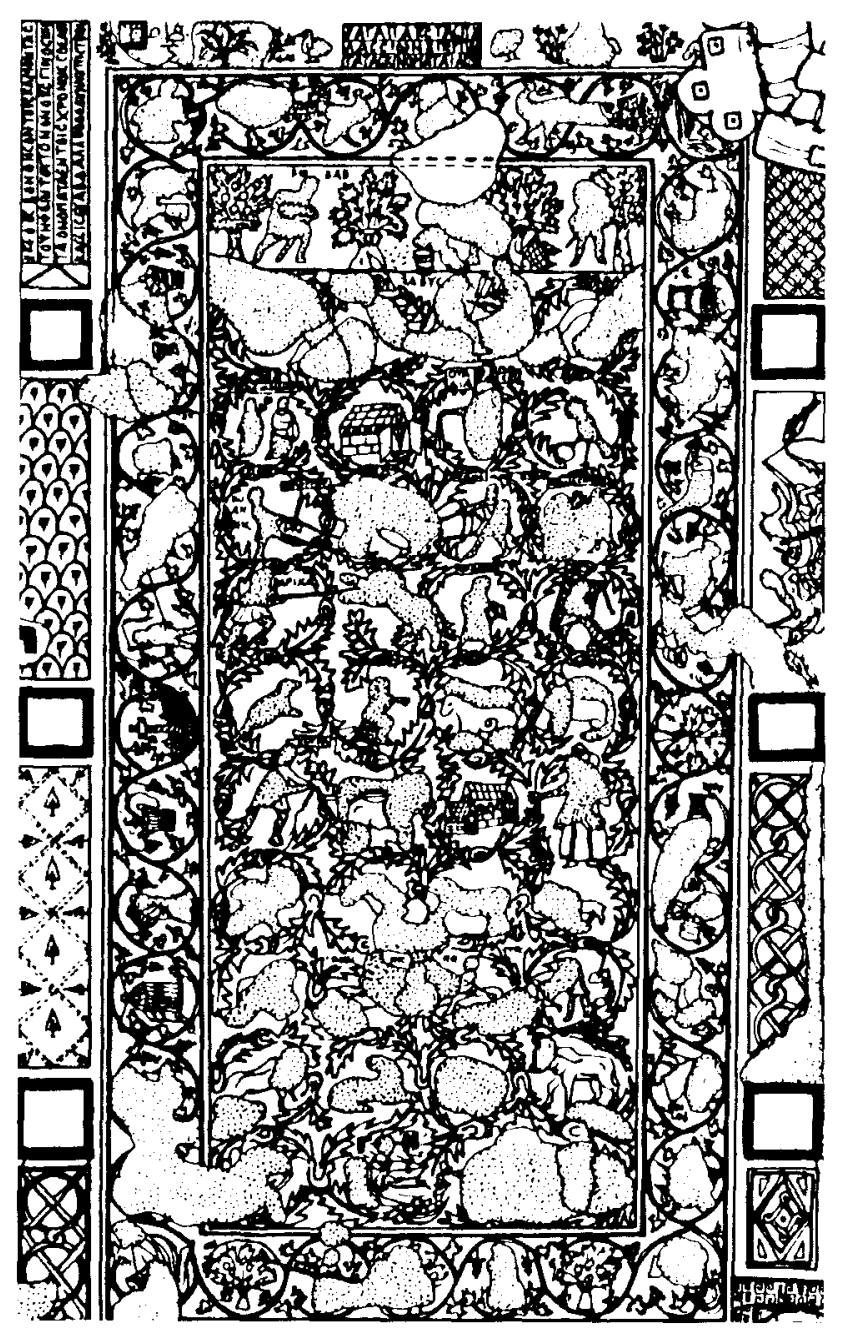

Fig. 10. Personificación del mar. Iglesia de Um er-Rasas (Piccirillo, 1996, pág. 234, fig. 365).

Océano, también identificado por la inscripción y por todos sus atributos, aparece en la iglesia descubierta hace pocos años en Petra (abajo). Y en otro mosaico cristiano de Jordania, en la iglesia del obispo Sergio de Um er-Rasas, se han conservado fragmentos de un complejo mosaico que incluía la figura del dios del mar, aquí identificado como ABY $\Sigma \Sigma O \Sigma$ por una inscripción fragmentaria (fig. 10). También se conserva parte de la vela de un navío (Piccirillo: 1993: 38, 234, figs. 365, 366). 
Pero volvamos a la figura singular de Thalassa. La figura femenina dentro del ancho círculo de un medallón es de larga tradición en Siria y Jordania, tanto para figuras mitológicas como para personificaciones de virtudes, como lo comenta Balty (1986:402) ${ }^{14}$. Su cabello liso delinea su rostro redondeado. Un manto o chal le cubre sólo el hombro izquierdo, dejando su pecho derecho desnudo. Va ataviada con un collarete y con brazaletes en la muñeca y brazo derechos, y levanta su mano en típica actitud de bendición o saludo. A su izquierda se yergue el timón, atributo de Tetis, mientras que peces y otros animales o pequeños monstruos marinos bailan a su alrededor. Son todo elementos que vemos en los mosaicos más clásicos del mismo tema en Shabha y Antioquía. Pero el estilo de la época le ha cambiado totalmente la expresión de la cara, que resulta fria e inexpresiva a pesar de sus grandes ojos. Alrededor del medallón con la personificación del mar tenemos una gran alfombra de mosaico formada por un tema repetitivo de pares de pájaros, flores y frutos.

El significado de esta composición, que combina la presencia solemne de la diosa del mar con otros elementos bellos de la naturaleza, podria parecernos difícil de comprender, y más como ornamento principal del pavimento de una iglesia. Pero no puede serlo tanto si, además de tener en cuenta el significado general y primario de esta decoración pavimental, que para nosotros es fundamentalmente la de la naturaleza en sus varios aspectos y estados ${ }^{15}$, leemos atentamente la inscripción con que los autores del mosaico tuvieron a bien rodear el busto de Thalassa. A pesar de su carácter dedicatorio, esta inscripción, que es una plegaria, nos da una clave muy clara: "Oh Señor Dios, tú que has hecho el cielo y la tierra, da la vida (en griego $\triangle \mathrm{O} \Sigma \mathrm{Z} \Omega \mathrm{HN}$ ) a Anastasio, Tomás, Teodora, y Salaminos el mosaísta" (Zayadine 1986: 421). Como bien notó el P. Bagatti (1968: 250), esta inscripción es una cita implícita del Salmo 145, cuyo versículo 6 comienza con las palabras: "El Señor, su Dios, que ha hecho el cielo y la tierra..." También aquí, pues, es el pensamiento bíblico de fondo el que parece conjuntar los diversos elementos que podrían parecernos disparatados. Se pide ante todo la vida, vida eterna, naturalmente, que aquí es sinónimo de aquella salvación que mencionamos en la introducción. Sabemos que Dios puede darla, puesto que es el creador del cielo y de la tierra, según el Salmo, y un elemento importante de esa tierra es justamente el mar y los seres que lo habitan.

Con buen acierto y a fin de facilitar la comparación, J. Balty presenta juntas en doble página las cuatro figuraciones de la Tetis de Shabha, la Thalassa de Madaba, la Megalopsychia de Antioquia, y la figura de Ge o Tierra (sin nombre), que aparece con sus frutos en un medallón en los murales de Qasr el-Heir (Balty 1986, figs. 5-8).

Véase Tomasevic 1995. 
Uno podría lógicamente preguntarse por qué el mosaista Salaminos no reprodujo, en vez de la diosa del Mar (Thalassa-Tetis), la diosa de la Tierra (Ge o Gaia), que aparece también representada en otros pavimentos de iglesia, como veremos. El texto escogido le habría cuadrado todavía mejor. Creemos encontrar la respuesta en el hecho de que la inscripción su inscripción es una plegaria, dirigida a Dios creador de todo y dador de la vida. La figura del mar, en ese caso, es descriptiva de esa vida. Los peces y los monstruos marinos son representación de ese poder vital que viene de Dios, y únicamente de él. No podemos afirmar que la diosa ThalassaTetis represente aquí al propio Dios creador y dador de vida. Pero sí decir que representa el poder de ese Dios creador y dador de vida. Es una figura alegórica del poder creador de Dios ${ }^{16}$. De hecho, la figura alegórica de la Tierra $(\mathrm{Ge})$, que era también figura divina, aparece también en un caso recibiendo el homenaje de los hombres, que le presentan sus frutos, o sea, representando prácticamente la propia Divinidad creadora y dadora de vida. Nuestra interpretación recibe plena corroboración con el paralelo de la figura central de Helios, el dios sol, que en los mosaicos con la representación del universo astral y temporal ocupa sin duda el lugar de la Divinidad creadora y sostenedora de la vida.

Posiblemente tengamos otra representación de la diosa del mar en la iglesia bizantine de Petra, descubierta hace pocos año y que se ha hecho célebre por el lote de papiros bizantinos encontrados en ella (Fiema 1992; Perleman 1993; Fiema-Schick-'Amr 1995). Desgraciadamente, no hemos podido obtener la reproducción para comentarla. También se encuentran alli las figuras alegóricas de la Tierra y del Mar, además de las cuatro Estaciones. Cada uno de estos personajes está aislado dentro de su recuadro en el mosaico del pavimento del ala sur de la basílica, e identificado con su nombre en griego (fig. 11). Toda la iglesia y su decoración son obra del siglo VI, pero no hay duda que, a pesar de la evolución estilística respeto a los modelos antiguos, ha habido un cuidadoso interés por la continuidad temática, que se acusa por ejemplo en los atributos de cada personaje ${ }^{17}$. De un modo general, el tema representado por todas esas figuras alegóricas es el mismo, pues se complementan entre ellas. Se trata de la naturaleza en sus diversos elementos: el mar

16 Zayadine no iba tan lejos en su interpretación: "Ce sont ensomme des personnages allégoriques. Téthys représente simplement, je crois, le royaume de Dieu qui règne sur la mer et sur la terre" (ZAYADINE 1986: 431).

17 Además, a juzgar por las dos figuras que vemos publicadas, la de la Primavera y la de Okeanós (NEGEV 1995:105), o hay una doble mano en la ejecución de los trabajos, o el artista ha empleado modelos de muy diverso estilo. 


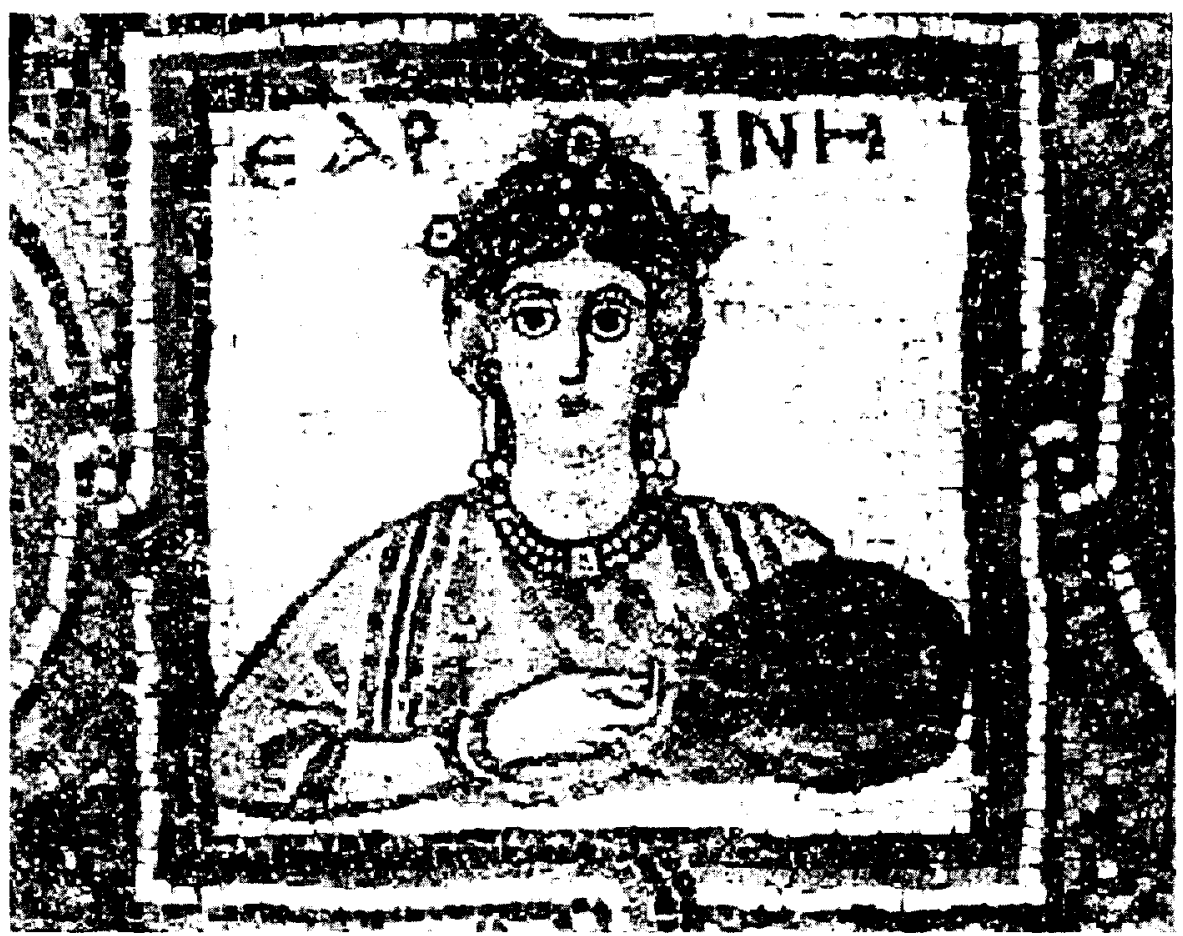

Fig. 11. Personoficación de la Primavera. Iglesia de Petra (Negev 1995, pág. 105).

con sus habitantes, la tierra que proporciona sus frutos, y estos dentro de su contexto temporal, según los diversos períodos del año. Pero sabemos que, además de estas figuras simbólicas, está también representada en este mosaico la personificación de la virtud de la Sabiduría, identificada con su nombre en griego, $\Sigma \Omega \Phi I A$. Dada la altísima importancia atribuida a esta palabra en la Biblia, como ya apuntamos en la Introducción, no creemos estar equivocados si también aquí interpretáramos su personificación como representando no ya una virtud humana, como requeriría la tradición artística helenístico-romana, sino la propia sabiduría divina, esto es, a Dios mismo. De ser asi, tendríamos un excelente paralelo a la figura de la diosa del mar en el mosaico de Mádaba, que comentamos antes.

En cuanto al dios del mar, $\Omega \mathrm{KEANO \Sigma}$ (fig. 12), aparece de cuerpo entero como un hombre maduro, con largos cabellos y barba blancos, vestido con un manto que le cuelga de su hombro izquierdo, cubriéndole solo medio cuerpo. Apoya su pie izquierdo sobre la cabeza de un delfín que 


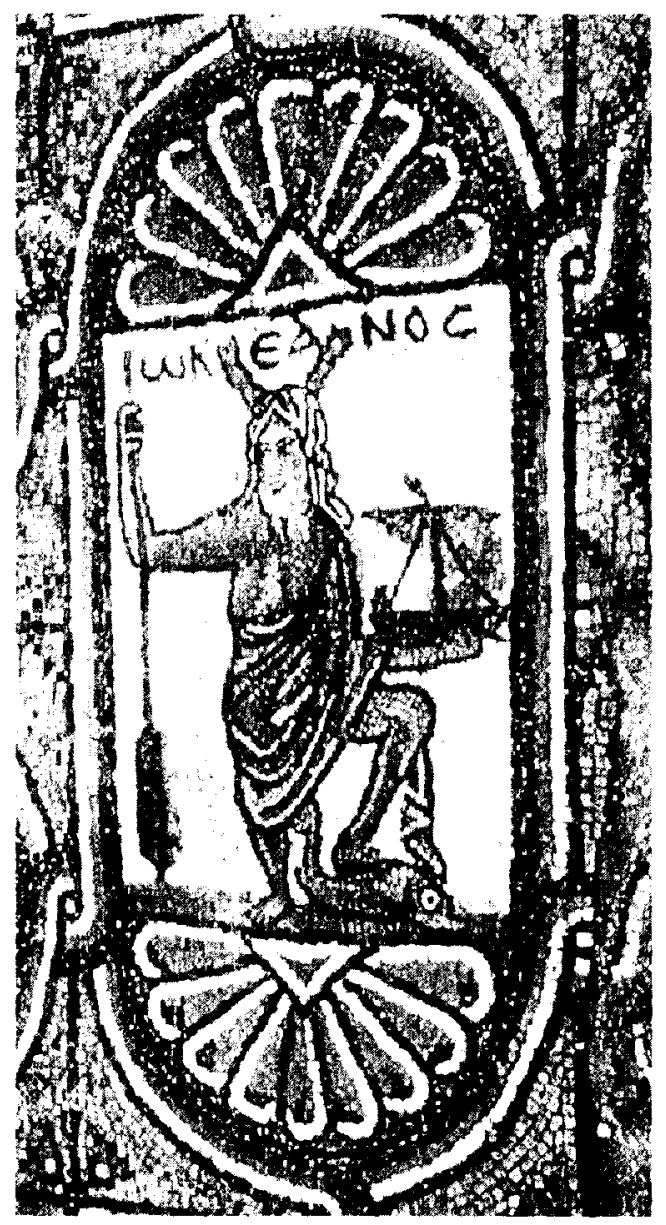

Fig. 12. Personificación del Océano. Iglesia de Petra (Negev 1995, pág. 105).

tiene la cola alzada. Con la mano derecha mantiene derecho en el suelo un timón, mientras que su izquierda sostiene la reproducción de una barca con la vela desplegada al viento. De la cabeza salen las dos tradicionales patas de cangrejo, atributo que no falta en ninguna de sus representaciones. Vale la pena notar, por lo demás, que es ésta la primera vez que el dios Océano aparece como tal en la iconografía cristiana antigua ${ }^{18}$. $Y$ no

18 Pero véase la figura del río Jordán, igualmente con cuernos de cangrejo en la cabeza, en el bautisterio de los Arrianos en Ravenna (arriba, n. 11). 
es de extrañar, si conocemos la animadversión que experimentaban los Padres de la Iglesia ante el tema de la conjunción de Tetis con Océano para imaginar el equilibrio de la naturaleza y del mundo entero ${ }^{19}$.

\section{LA TIERRA Y SUS FRUTOS}

Este tema es el complemento al motivo del agua y sus habitantes. Tierra es el elemento primordial, creado por Dios desde el principio (Génesis 1:1), adamá en el texto hebreo de la Biblia, del cual no sólo fue formado el hombre, adam, sino que fueron producidas todas las demás creaturas animadas, tanto animales como plantas. La tierra, que se llama ge tanto en griego clásico como en las traducciones griegas de la Biblia, fue también elevada a la diginidad de diosa en el mundo helénico. No parece que haya existido una civilización primitiva que no haya tributado su culto a la madre tierra. Es el gran principio femenino, el principio de la vida, del que todo proviene y al que todo vuelve. Nada tiene de extraño pues, que griegos y romanos hubiese sentido también la necesidad de representar entre sus figuras preferidas, a la más humana de las diosas, la madre tierra, hija de Caos, madre y esposa de Uranós, de la que nacieron infinidad de seres divinos y humanos. En la época romana, y ya identificada con la Tellus itálica, la vemos representada con mucha frecuencia en las casas señoriales de Antioquía y Apamea, a veces acompañada de los Karpoi, los genios de los frutos (Levi 1947, II: PI. LII; House of Aion, ibid. PI. LXXXIV, c-d; Balty 1977:28-29), otras veces junto a las estaciones del año (Levi 1947, II: Pls. LXXXI, a-b; CLXIX, a; Balty 1973; 1997:72-75; Donceel-Voûte 1995:96, fig 9; Chéhab 1958:129). Podemos decir que aquí, la figura no es ya tanto una representación de la diosa Tierra como una alegoría de la tierra misma, del elemento sólido del cosmos. En la mayoría de casos, la figura de Ge aparece en busto dentro de gran medallón, aunque también podemos verla de cuerpo entero (Levi 1947, II: PI. CLXIV, a). En un gran mosaico de Shahba-Philippopolis, aparece de cuerpo entero, sentada y rodeada por pequeños Karpoi, en el centro de un cuadro en el que están también Aión. Prometeo y otras muchas alegorias de los elementos del tiempo, incluyendo también a Georgia, la agricultura. En la villa romana

19 Juan Crisóstomo tiene un texto muy elocuente en este sentido: «Pues efectivamente, no es realmente un pequeño argumento de reflexión aquel punto en que se ve como Océano se reconcilia con Tetis por intermedio de Hera, ataviada como una cortesana. Puesto que habría peligro para el mundo entero si por un tiempo guardasen continencia, ya sea que la parte seca y la parte húmeda de la naturaleza tuviesen que reconciliarse a fin de que no se derrumbase todo por el exceso de una de las dos, ya sea que tú pienses en cualquier otra interpretación de estos hechos todavía más absurda" (JuAn Crisóstomo, Contra Juliano el Apóstata, Oratio IV, 116. 2). 


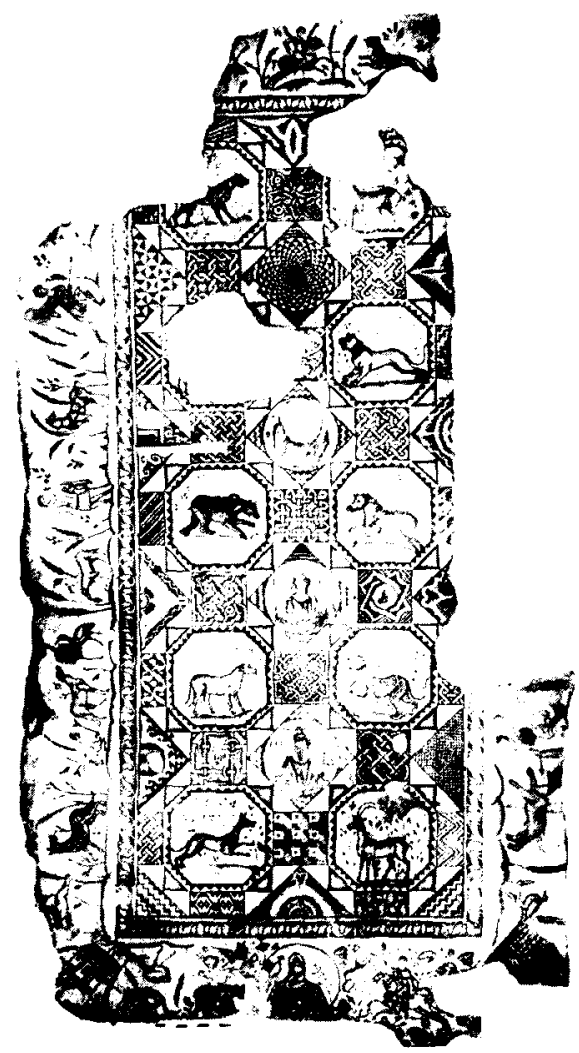

Fig. 13. Mosaico con la figua de Gé y las estaciones. Villa romana, Bet Guvrin (Talgam 1998, pág. 81).

de Awa'i, en el Libano, aparece también de esta forma, acusando ya un fuerte frontalismo, en el centro de un mosaico, pero no va acompañado de la inscripción $\mathrm{GH}$, como es costumbre (Chéhab 1958, PI. LXXXIX). También aparece $\mathrm{Ge}$ en algunas villas romanas de Israel, siendo muy conocida la de Bet Guvrin (fig. 13), en medallón central de alfombra musiva de una gran sala rectangular, en la que aparecen igualmente dos estaciones del año (Vincent $1922^{20}$; Avi-Yonah 1981: PI. 49) ${ }^{21 .}$

20 Curiosamente, en su descripción Vincent (pág. 263) llama «nymphe» a esta figura alegórica de la tierra. Según la mitología griega, tambièn las ninfas eran hijas de Gea.

¿1 Por comunicación verbal del arqueólogo que la excavó, sabemos que existe otra, extrañamente no publicada, procedente de Tel Malhata en el norte del desierto del Néguev, y que se conservaria hoy día en la base militar aérea de Nevatim, muy cerca del lugar donde fue descubierta. 


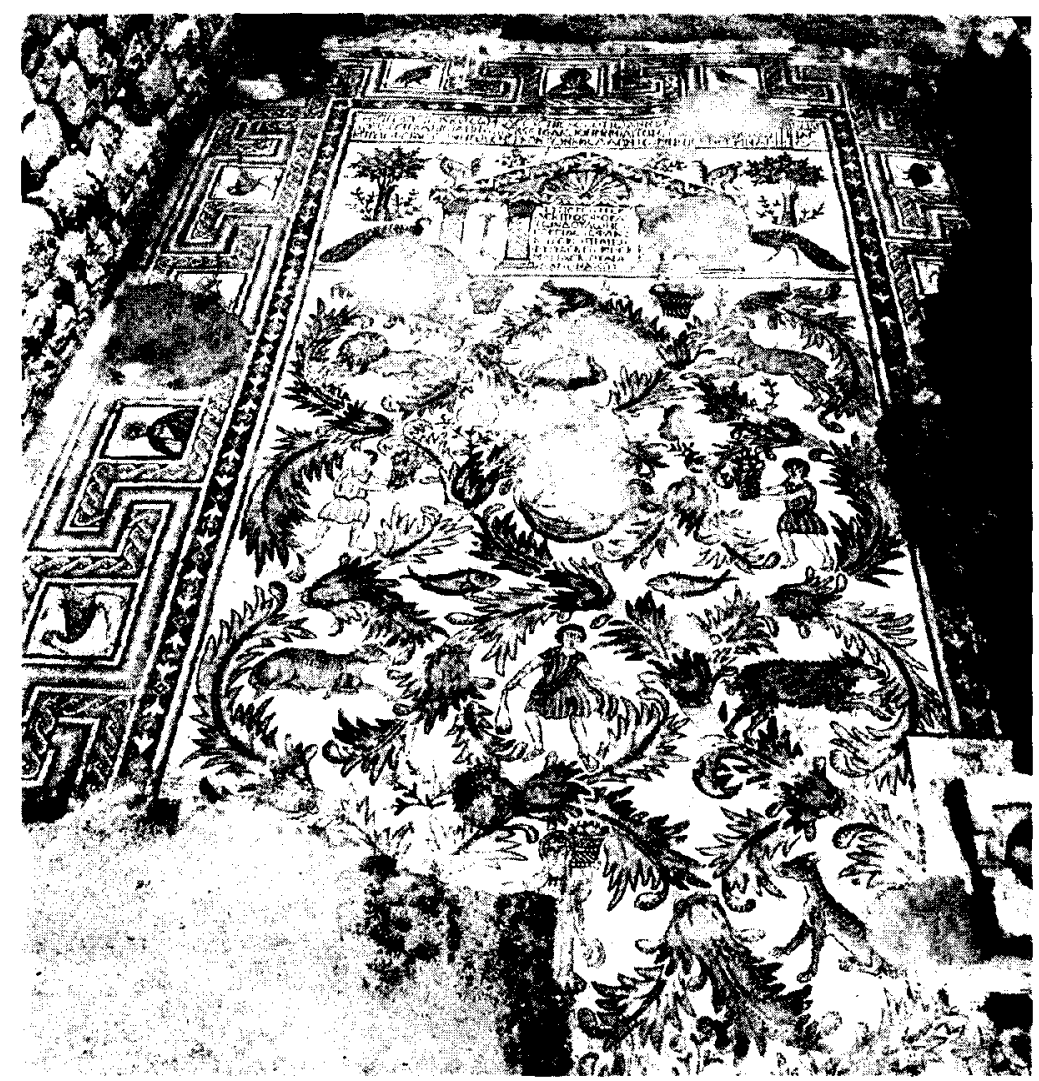

Fig. 14. Mosaico de Gea y los Karpoi, iglesia del El Mukhayyat, en su estado actual (Piccirillo 1986a, pág. 213, fig. 1).

Comprendiendo la importancia decorativa y la frecuencia con que vemos a esta figura mítica de Tierra ¿cuál será su función cuando la encontramos decorando igualmente, e incluso acompañada a veces de un contexto más significativo, el pavimento de una iglesia? Es así que hoy la tenemos nada menos que cuatro veces en Jordania: en la Iglesia del obispo Sergio de Umm er-Rasas, lado oeste del pavimento central, con inscripción (Piccirillo 1993: 38, 234, figs. 365 y 368; id. 1995:80, fig. 19), en la capilla del presbítero Juan de la iglesia de Amós y Kasiseos de la ciudad del Monte Nebó (El-Mukhayyat) (fig. 14), en el mosaico central de la iglesia de San Jorge de la misma ciudad (Saller-Bagatti 1949: 3338, 180-182; Talgam 1998: 85), y también en la iglesia de Petra, la misma en que ya encontramos a Océano (Fiema 1993; Perleman 1994: fig. 45). 


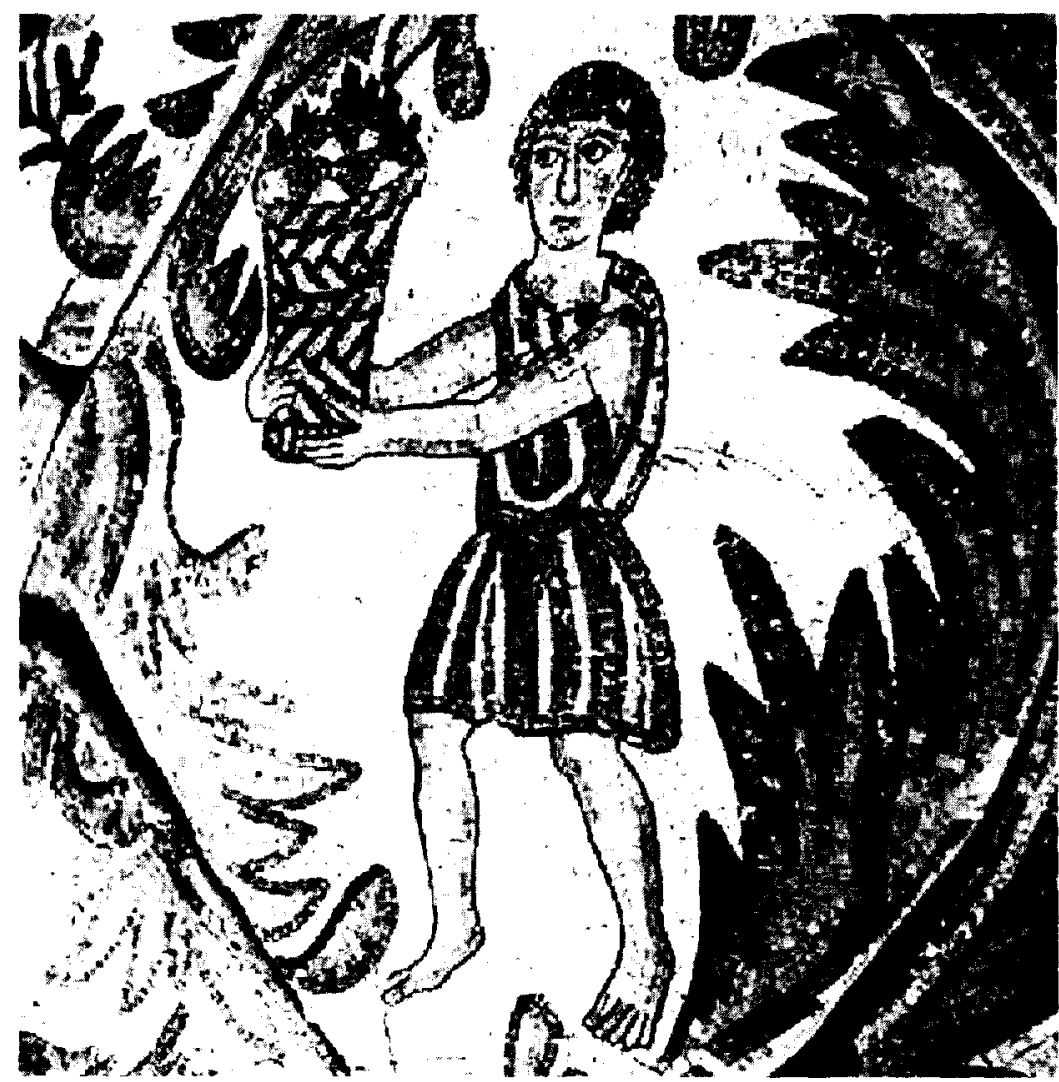

Fig. 15. Figura de Karpos ofreciendo los frutos a Gea. Iglesia del El Mukhayyat, Monte Nebó (Talgam 1998, cubierta).

En los dos casos de la personificación de la Tierra en las iglesias de la ciudad del Monte Nebó, aquella aparece ocupando el espacio de un medallón central, no bien definido por cuatro grandes ramas de acanto. Pero lo que más llama la atención en esas dos imágenes de Gea, la Tierra, es el hecho de que se la representa flanqueada por dos jóvenes que le ofrecen sendas cestas llenas de frutos (fig. 15). Son figuras que han evolucionado de los tradicionales genios de los frutos, los Karpoi, que aparecen generalmente como niños o erotes en tantas reproducciones paganas de la madre tierra ${ }^{22}$. Además, ella misma sostiene ya (o

22. Los vemos no sólo en mosaicos profanos orientales (Casa de Aion en Antioquia, s. vi d.C.), sino también en sarcófagos romanos del siglo III (LIMC, VIII, Tellus, 23-25). En un desaparecido 
sostenía) ${ }^{23}$ con sus manos un amplio lienzo o un pliegue de su manto, también lleno de frutos, los frutos que ella concede a los hombres que, trabajándola, obtienen de ella el sustento. Es una escena como de mutuo ofrecimiento de los frutos: de la tierra a los hombres y de los hombres a la tierra. Considerándola de este modo, la escena no está demasiado apartada de la explicación que desarrolla con gran extensión Juan Crisóstomo en una de sus homilias, acerca de las relaciones existentes entre los hombres y la tierra, de la que todos venimos y a la que todos volvemos ${ }^{24}$.

Pero es evidente que ni Juan Crisóstomo ni ningún otro de los demás escritores cristianos que tocaron el tema de la tierra, habian imaginado la tierra como dotada de unos atributos divinos, aunque sí la habian a veces imaginado casi como a una persona viva ${ }^{25}$. En cambio, cuando tocaba a los artistas cristianos poner en ejecución un plan premeditado de decoración del pavimento de la iglesia, no encontraban otro modelo iconográfico para representar la tierra que el tradicional de la divina $\mathrm{Ge}, \mathrm{Y}$ es con los atributos de esa divinidad como en la capilla del presbítero Juan, por ejemplo, la representaron, ricamente vestida, ataviada con collaretes, con el cabello lleno de frutos, resaltado por una especie de halo radiado en forma de gran hoja de vid (Buschhausen 1986: fig. 82). Eso significa, como mínimo, que poco les importaban aquellas conexiones paganas a los responsables eclesiásticos de la realización de aquella decoración. Es más, nosotros estamos convencidos de que la aparición de esta figuras paganas en las iglesias no respondian tan sólo a un supuesto renacimiento clásico en la época de Justiniano, como podrían ser los mosaicos en ambientes no cultuales ${ }^{26}$, sino a un programa pensado y lleno de intención. Dado el simbolismo cosmológico que se atribuía a la decoración interior

mosaico de Cartago aparecia la diosa Tierra como figura central dentro de un círculo rodeado por los meses del año y las estaciones, que le presentaban cestos llenos de frutos (Parrish 1984: PI. 19).

23 Desgraciadamente, depués de su descubrimiento y publicación la figura de Tierra ha sido casi totalmente destruida en el mosaico de la capilla del presbitero Juan. Pero las fotografías que se publicaron al principio muestran bien todos los detalles, incluida la inscripción GH.

${ }^{24}$ Hom. IX, PG ... Véanse los comentarios al respeto por parte de Maguire, que admite igualmente esa relación entre la figuración en el mosaico y la explicación patrística.

25 Comentando el Eclesiastés, dice Gregorio de Nisa: “Y la tierra se mantiene firme". ¿Qué hay más difícil que esta firmeza inamovible y esa estabilidad? Y sin embargo, su firmeza se mantiene por toda la eternidad: tu lucha, en cambio, es de poca duración. No seas menos valiente que la tierra..." (GREgorio DE Nisa, Sobre el Eclesiastés, Homilía I, PG 44, 628).

26 Estos serían los mosaicos encontrados en la acrópolis de Mádaba, esto es, la llamada Sala de Hipólito (PICCIRILlo 1993: 23-24 (fig .XI), 49, 51 (fig. 3), 52 (fig. 4), 53 (fig. 5), 54-55 (fig. 6), 65 (fig. 23), 66, figs. 1, 3, 5, 6, 23], los fragmentos de Aquiles (ibid.: 26, 76-78, figs. 32, 43, 48), de los danzantes báquicos (IBID.: figs. 33,43 ) y de Hércules (IBID.: 80, fig. 55) 
del lugar de culto cristiano, la temática de las decoraciones musivas de los pavimentos no podían ser escogidos más que de entre temas que forzosamente girarian en torno a la idea del mundo terrenal, de los animales y las plantas, del hombre y sus trabajos, y de los dos principales elementos que formaban propiamente el mundo material, o sea, el agua y la tierra ${ }^{27}$. La tierra en todas sus formas vitales era la idea básica a que deberían atenerse los que iban a programar el mosaico, de acuerdo con los donantes y las autoridades eclesiásticas. ¿Qué más natural que la personificación de la misma tierra, puesto que sabian cómo podía representarse según la tradición? Luego, a partir de la figura tradicional de la $\mathrm{Ge}$, la que regalaba y la que recibía, símbolo de la abundancia de los dones de Dios, cada cual podría interpretar la escena representada según sus propios conocimientos, tanto bíblicos como filosóficos y teológicos, e incluso según su propio gusto. Todos sabian, sin duda, que la abundancia de la tierra venía del mismo Dios. Una figura alegórica de la tierra presentada con atributos divinos evocaría fácilmente en muchos la propia Divinidad en su actitud de donación y conservación de la vida, eje central alrededor del cual giraba toda manifestación de vida, principio mantenedor de todo lo creado, del cual se recibía todo, al cual se daba gracias por todo, y al cual finalmente todo y todos iban a volver ${ }^{28}$. En definitiva, era la misma idea que apuntábamos arriba para la interpretación de la presencia de la diosa del mar en los mosaicos de iglesia.

\section{BIBLIOGRAFIA}

Afoldi-Rosenbaum, E. (1975): "A Nilotic Scene on Justinianic Floor Mosaics in Cyrenaican Churches", en La mosaïque gréco-romaine II, Paris, págs. 149-153, PIs. LV-LVIII (Bet Leontis pl. LVIII, 2).

Avi-Yonah, M. (1972a): La Terre Sainte (Guides Culturels du Monde), Paris.

Avi-Yonat, M. (1972b): “Haditha Mosaic Pavement", Israel Exploration Journal 22:118-122.

Avi-YONAH, M. (1981): Art in Ancient Palestine (trabajos reeditados por Hanna Katzenstein y Yoram Tsafrir), Jerusalem.

BALTY, J. (1973): "Mosaïque de Gé et des Saisons à Apamée", Syria 50:311-347, Pls. XVXVIII.

2/ Véase TOMASEVIC 1995.

${ }_{28}$ La idea del retorno a la tierra era ya naturalmente pagana, no sólo judia y cristiana. En sarcófagos paganos vemos a veces a la figura de Tierra justo debajo del clypeus en el que aparecen los bustos de los difuntos, reclinada en tierra, sosteniendo en sus manos el cuerno de la abundancia y acompañada por los Karpoi. Viene asi a complementar el simbolismo de la vida de las demás figuras, las Estaciones del año, que en forma de genios alados sostienen el circulo del clypeus (véase P. ChauviN 1999, "Le triomphe du calandrier chrétien", Le Monde de la Bible, 118:41, fig). En el tan conocido sarcófago cristiano de lulius Bassus la Tierra aparece sin tanto acompañamiento, y como sirviendo de apoyo a los pies de Jesús, representado en majestad, sentado en el centro de toda la escena, como verdadero señor de vida y muerte. 
BALTY, J. (1986): “Iconographie classique et identités regionales: les mosaïques romaines de Syrie», en Kahil et al. 1983, págs. 395-406.

BuschHAusEN, H. (ed.) (1986a): Byzantinische Mosaiken aus Jordanien, Wien.

Buschinusen, H. (1986b): “Die Marienkirche von Madaba und der Saal des Hippolytos", en Buschhausen 1986a, págs. 139-156

CHËAB, M. (1957-1959): Mosaiques du Liban, Paris.

Donceel-Voúte, P. (1995): "Syro-Phoenician mosaics of the $6^{\text {th }}$ century", en Ling (ed.) Fith International Colloquium on Ancient Mosaics, Ann Arbor, 1995, págs. 88-100.

Edelstein, G. (1990): ['Ein Ya'el Villa], Biblical Archaelogy Review, nov.-dec. 1990:32-42.

EDELSTEIN, G. (1993): “A Roman Villa at 'Ein Ya'el», Qadmoniot 26 (103-104):114-119 (en hebreo).

FIEMA, Z.T. (1993): "Jordanie: une église byzantine à Pétra", Le Monde de la Bible 83:45.

Fiema, Z.T. (s.a.): Petra Church Project, in ACOR: The First 25 years, American Center of Oriental Research 1968-1993, págs. 69-71.

FIEMA, Z.T.; SCHICK, R. and AMR, K. (1995): "The Petra Church Project-Interim Report, 199294", en J.H. Humphrey (ed.), The Roman and Byzantine Near East-Some Recent Archaeological Research, Ann Arbor, 1995, págs. 287-303.

HACHLILI, R. (1997): "Aspects of Similartiy and Diversity in the Architecture and Art of Ancient Synagogues and Churches in the Land of Israel», Zeitschrift des Deutschen PalästinaVereins 113:92-115.

Kahil, L.; Auge, C.; LinANt de Bellefonds, P. (eds.) (1986): Iconographie classique et identités régionales, Paris 26 et 27 mai 1983, Athens-Paris.

KITZINGER, E. 1965, "Stylistic Developments in Pavement Mosics in the Greek East from the Age of Constantine to the Age of Justinian», La Mosaique Gréco-Romaine, I, Paris, págs. 341-352.

LAVIN, I. (1963): "The Hunting Mosaics of Antioch and Their Sources", Dumbarton Oaks Papers $17: 181-286$.

LEVI, D. (1947): Antioch Mosaic Pavements, Vols. I-II, Princeton.

NeGEV, A. (1995): "Petra Research», Qadmoniot 28 (110):97-112 (en hebreo).

NetZer, E. and Weiss, Z. (eds.), 1992, "Byzantine Mosaics at Sepphoris-New Finds", Israel Museum Journal 10:75-80.

NETZER, E. and WEISS, Z. (1993): "Sepphoris (Sipori), 1991-1992", Israel Exploration Journal 43:190-196

Netzer, E. and Weiss, Z. (1995): "New Evidence for Late Roman and Byzantine Sepphoris", en J. H. Humphrey (ed.) The Roman and Byzantine Near East -Recent Archaeological Research (Journal of Roman Archaeology Suplementary Series, XIV). Ann Arbor (Mi.) 1995, págs. $162-176$

NETZER, E. and WEISS, Z. (1997): “Excavations at Sephoris", Qadmoniot 30 (113):2-21 (en hebreo).

PARRISH, D. (1984): Season Mosaics of Roman North Africa, Rome.

Perleman, G.L. (1994): "Sensationnelle découverte: des manuscrits byzantins à Pétra", Le Monde de la Bible 88:40-41.

PICCIRILlO, M. (1986a): "Die Mosaiken von Justinian bis Jazid Il», en Buschhausen 1986a: 27 121.

Piccirillo, M. (1986b): "La cité de Nébo", Le Monde de la Bible 44: 30-39.

Piccirillo, M. (1993): The Mosaics of Jordan, Amman.

PICCIRILlo, M. (1995): “ll mosaico pavimentale di Giordania come fonte storica di un'epoca: Ill (1985-87)", en Ling (ed.) Fith International Colloquium on Ancient Mosaics, Ann Arbor, 1995, págs. 65-87.

RAPUANO, Y. (1989): “'Ein Ya'el 1987", Israel Exploration Journal 39:112-115.

SALLER, S.J. and BAGATTI, B. (1949): The Town of Nebo (Khirbet el-Mekhayyat) with a brief summary of other Christian monuments in Transjordan, Jerusalem.

TALGAM, R. (1998): "Mosaics in Israel in the Light of Recent Discoveries", Qadmoniot 31 (116): 74-89 (en hebreo).

TALGAM, R.-WEISS, Z. (1988): "The Dionysus Cycle' in Sepphoris Mosaic", Qadmoniot 21 (8384): $93-99$ (en hebreo).

TOMASEVIC, G. C. (1995): «Représentations symboliques du cosmos dans l'art figuratif et dans l'architecture", en R. Ling (ed.). Fifth International Colloquium on Ancient Mosaics, Part Two, Ann Arbor, 1995, págs. 279-292.

VINCENT, H. (1922): “Une villa grèco-romaine à Beit Djebrin", Revue Biblique 19:259-281, pl. VIII-X. WEISS, Z.-NETZER, E. (1994): Zippori, Jerusalem (en hebreo).

WEISS, Z.-TALgam, R. (1980): "The Dionysiac Mosaic Floor of Sepphoris", en VI Coloquio internacional sobre mosaico antiguo, Palencia-Mérida, págs. 231-237.

ZaYADINE, E. (1986): «Peintures murales et mosaïques à sujets mythologiques en Jordanie», en Kahil et. al. 1986:407-432. 